Prepared in cooperation with the City of Portland Bureau of Environmental Services

\title{
Developing Flood-Inundation Maps for Johnson Creek, Portland, Oregon
}

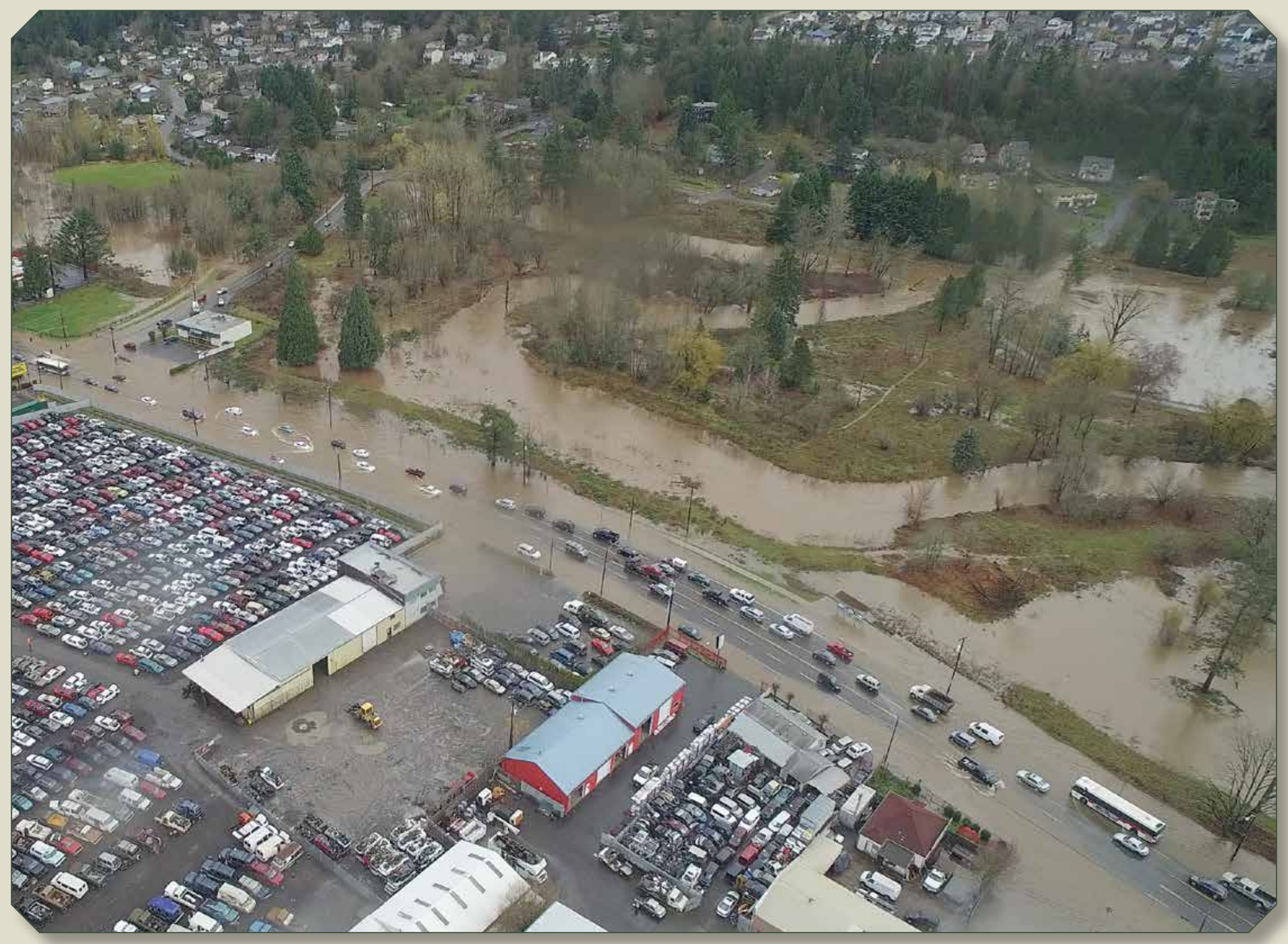

Scientific Investigations Report 2017-5024

U.S. Department of the Interior

U.S. Geological Survey 
Cover: Aerial view of Johnson Creek Floodplain during December 2015 flood event, Portland, Oregon. Photograph by Adam Simmons, Twelvizm, December 7, 2015. Used with permission. 


\section{Developing Flood-Inundation Maps for Johnson Creek, Portland, Oregon}

By Adam J. Stonewall and Benjamin A. Beal

Prepared in cooperation with the City of Portland Bureau of Environmental Services

Scientific Investigations Report 2017-5024 


\title{
U.S. Department of the Interior \\ RYAN K. ZINKE, Secretary
}

\section{U.S. Geological Survey William H. Werkheiser, Acting Director}

\author{
U.S. Geological Survey, Reston, Virginia: 2017
}

For more information on the USGS - the Federal source for science about the Earth, its natural and living resources, natural hazards, and the environment-visit https://www.usgs.gov or call 1-888-ASK-USGS.

For an overview of USGS information products, including maps, imagery, and publications, visit https://store.usgs.gov.

Any use of trade, firm, or product names is for descriptive purposes only and does not imply endorsement by the U.S. Government.

Although this information product, for the most part, is in the public domain, it also may contain copyrighted materials as noted in the text. Permission to reproduce copyrighted items must be secured from the copyright owner.

Suggested citation:

Stonewall, A.J., and Beal, B.A., 2017, Developing flood-Inundation maps for Johnson Creek, Portland, Oregon: U.S. Geological Survey Scientific Investigations Report 2017-5024, 26 p., https://doi.org/10.3133/sir20175024.

ISSN 2328-0328 (online) 


\section{Contents}

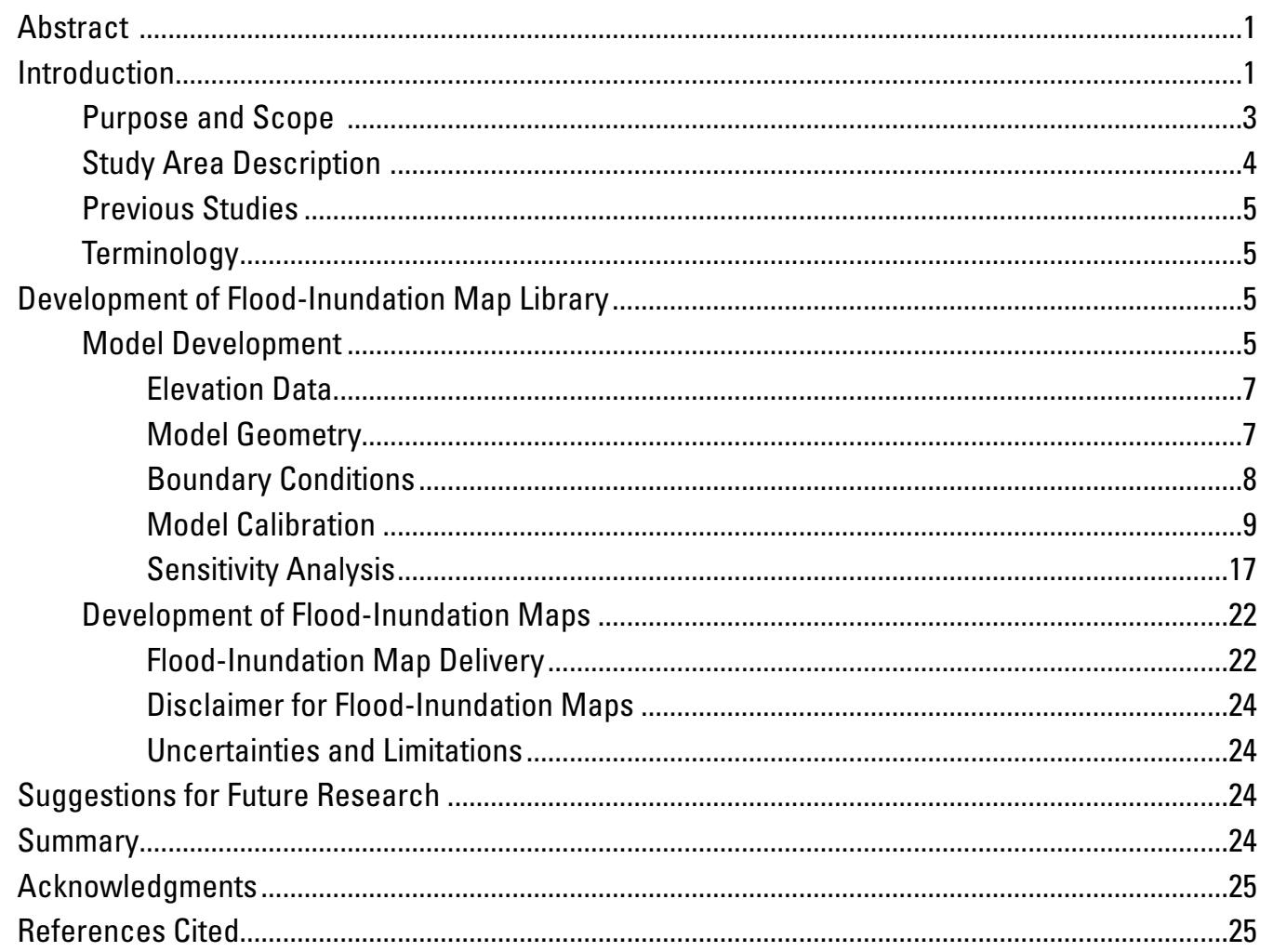




\section{Figures}

1. Map showing location of study area, Johnson Creek watershed, near Portland, Oregon

2. Graph showing relation between peak annual streamflow at U.S. Geological Survey streamgage on Johnson Creek at Sycamore (14211500) and ratio of peak annual streamflow at Sycamore streamgage to peak annual streamflow at Milwaukie streamgage (14211550), Johnson Creek, Oregon, water years 1990-2014

3. Graph showing relation between peak annual streamflow at U.S. Geological Survey streamgages on Johnson Creek at Sycamore (14211500) and Kelley Creek at SE 159th Drive at Portland, Oregon (14211499), Oregon, water years 2001-14

4. Aerial image with map overlay showing position of the profile line used to estimate maximum depth on SE Foster Road, and example of a Hydrologic Engineering Center River Analysis System (HEC-RAS) profile output for model plan Steady_15ft_smooth, Johnson Creek, Oregon

5. Graphs showing relation between modeled and measured streamflow and stage at the U.S. Geological Survey streamgage on Johnson Creek at Sycamore (14211500; River Station 57287.5) during flood event, Johnson Creek, Oregon, December 2015......12

6. Graphs showing relation between modeled and measured streamflow and stage at the U.S. Geological Survey streamgages on Johnson Creek at Milwaukie (14211550; River Station 3690.7) during flood event, Johnson Creek, Oregon, December 2015

7. Graphs showing relation between modeled and measured streamflow and stage at the U.S. Geological Survey streamgage on Johnson Creek at Sycamore (14211500; River Station 57287.5) during flood event, Johnson Creek, Oregon, January 2009.

8. Graphs showing relation between modeled and measured streamflow and stage at the U.S. Geological Survey streamgage on Johnson Creek at Milwaukie (14211550; River Station 3690.7) flood event, Johnson Creek, Oregon, January 2009.

9. Graph showing comparison of large streamflow flood events at the U.S. Geological Survey streamgage on Johnson Creek at Sycamore (14211500), Oregon

10. Graph showing upper boundary conditions for Hydrologic Engineering Center-River Analysis System Johnson Creek model plans Unsteady_16ft_cond, Unsteady_16ft, and Unsteady_16ft_ext, December 2015

11. Map showing comparison of condensed unsteady, unsteady, and extended unsteady flow at the U.S. Geological Survey streamgage on Johnson Creek at Sycamore (14211500) stage of 16 feet, Foster Floodplain, Portland, Oregon

12. Graph showing upper boundary condition for streamflow input file of the steady plan at stage 16 feet, modeled on December 2015 flood event.

13. Map showing comparison of unsteady and steady flow extent at the U.S. Geological Survey streamgage on Johnson Creek at Sycamore (14211500) stage of 16 feet (ft), Foster Floodplain, Portland, Oregon

14. Map showing comparison of steady and unsteady flow plans at U.S. Geological Survey streamgage on Johnson Creek at Sycamore (4211500) stage of 15 feet, Foster Floodplain, Portland, Oregon... 


\section{Tables}

1. Largest recorded floods at U.S. Geological Survey streamgage, Johnson Creek at Sycamore (14211500), Oregon ..

2. List of Hydrologic Engineering Center River Analysis System model plans for this study using U.S. Geological Survey streamgage on Johnson Creek at Sycamore (14211500), Oregon...

3. Acquired geospatial (surveyed) data compared against published City of Portland, Oregon benchmarks

4. Comparison of modeled and measured high water marks for flood event at Johnson Creek, Oregon, December 2015

5. Comparison of modeled and measured high water marks for flood event, Johnson Creek, Oregon, January 2009.

6. Rating curve for the U.S. Geological Survey streamgage on Johnson Creek at Sycamore (14211500), Oregon

\section{Conversion Factors}

U.S. customary units to International System of Units

\begin{tabular}{|c|c|c|}
\hline Multiply & By & To obtain \\
\hline \multicolumn{3}{|c|}{ Length } \\
\hline foot $(\mathrm{ft})$ & 0.3048 & meter $(\mathrm{m})$ \\
\hline mile (mi) & 1.609 & kilometer $(\mathrm{km})$ \\
\hline \multicolumn{3}{|c|}{ Area } \\
\hline acre & 4,047 & square meter $\left(\mathrm{m}^{2}\right)$ \\
\hline acre & 0.4047 & hectare (ha) \\
\hline square mile $\left(\mathrm{mi}^{2}\right)$ & 259.0 & hectare (ha) \\
\hline square mile $\left(\mathrm{mi}^{2}\right)$ & 2.590 & square kilometer $\left(\mathrm{km}^{2}\right)$ \\
\hline \multicolumn{3}{|c|}{ Volume } \\
\hline acre-foot (acre-ft) & 1,233 & cubic meter $\left(\mathrm{m}^{3}\right)$ \\
\hline \multicolumn{3}{|c|}{ Flow rate } \\
\hline cubic foot per second $\left(\mathrm{ft}^{3} / \mathrm{s}\right)$ & 0.02832 & cubic meter per second $\left(\mathrm{m}^{3} / \mathrm{s}\right)$ \\
\hline
\end{tabular}

Temperature in degrees Celsius $\left({ }^{\circ} \mathrm{C}\right)$ may be converted to degrees Fahrenheit $\left({ }^{\circ} \mathrm{F}\right)$ as follows:

$$
{ }^{\circ} \mathrm{F}=\left(1.8 \times{ }^{\circ} \mathrm{C}\right)+32
$$

Temperature in degrees Fahrenheit $\left({ }^{\circ} \mathrm{F}\right)$ may be converted to degrees Celsius $\left({ }^{\circ} \mathrm{C}\right)$ as follows:

$$
{ }^{\circ} \mathrm{C}=\left({ }^{\circ} \mathrm{F}-32\right) / 1.8 \text {. }
$$

\section{Datums}

Vertical coordinate information is referenced to the North American Vertical Datum of 1988 (NAVD 88).

Horizontal coordinate information is referenced to the North American Datum of 1983 (NAD 83).

Elevation, as used in this report, refers to distance above the vertical datum. 



\title{
Developing Flood-Inundation Maps for Johnson Creek, Portland, Oregon
}

\author{
By Adam J. Stonewall and Benjamin A. Beal
}

\section{Abstract}

Digital flood-inundation maps were created for a 12.9-mile reach of Johnson Creek by the U.S. Geological Survey (USGS). The flood-inundation maps depict estimates of water depth and areal extent of flooding from the mouth of Johnson Creek to just upstream of Southeast 174th Avenue in Portland, Oregon. Each flood-inundation map is based on a specific water level and associated streamflow at the USGS streamgage, Johnson Creek at Sycamore, Oregon (14211500), which is located near the upstream boundary of the maps. The maps produced by the USGS, and the forecasted flood hydrographs produced by National Weather Service River Forecast Center can be accessed through the USGS Flood Inundation Mapper Web site (http://wimcloud.usgs.gov/apps/ FIM/FloodInundationMapper.html).

Water-surface elevations were computed for Johnson Creek using a combined one-dimensional and two-dimensional unsteady hydraulic flow model. The model was calibrated using data collected from the flood of December 2015 (including the calculated streamflows at two USGS streamgages on Johnson Creek) and validated with data from the flood of January 2009. Results were typically within 0.6 foot $(\mathrm{ft})$ of recorded or measured water-surface elevations from the December 2015 flood, and within $0.8 \mathrm{ft}$ from the January 2009 flood. Output from the hydraulic model was used to create eight flood inundation maps ranging in stage from 9 to $16 \mathrm{ft}$. Boundary condition hydrographs were identical in shape to those from the December 2015 flood event, but were scaled up or down to produce the amount of streamflow corresponding to a specific water-surface elevation at the Sycamore streamgage (14211500). Sensitivity analyses using other hydrograph shapes, and a version of the model in which the peak flow is maintained for an extended period of time, showed minimal variation, except for overbank areas near the Foster Floodplain Natural Area.

Simulated water-surface profiles were combined with light detection and ranging (lidar) data collected in 2014 to delineate water-surface extents for each of the eight modeled stages. The availability of flood-inundation maps in conjunction with real-time data from the USGS streamgages along Johnson Creek and forecasted hydrographs from the National Weather Service Northwest River Forecast Center will provide residents of the watershed and emergency management personnel with valuable information that may aid in flood response, including potential evacuations, road closures, and mitigation efforts. In addition, these maps may be used for post-flood recovery efforts.

\section{Introduction}

Johnson Creek is in northwestern Oregon, on the eastern side of the Portland metropolitan region and begins near the city of Boring, flowing through Multnomah and Clackamas counties and the cities of Gresham, Portland, and Milwaukie for about $26 \mathrm{mi}$, before its confluence with the Willamette River (fig. 1). More than 180,000 people live in the watershed (Johnson Creek Watershed Council, 2012). Although the headwaters of Johnson Creek are largely rural or agricultural, the lower reaches of the watershed are heavily urbanized, and many of the surface flows are diverted to combined sewer systems and sumps.

Development in the Johnson Creek watershed has resulted in significant perturbations to the channel and watershed. In 1849, a 10-foot dam was erected on the creek for use with a sawmill to cut old-growth timber from around the watershed (Johnson, 1992). The dam was later washed out by a flood, and replaced with a bigger dam that was used in conjunction with another sawmill until 1888. After gaining ownership of the land in 1903, the Oregon Water Power and Railway Company filled the east end of Johnson Creek Canyon for a railroad bed. Subsequently, 9 acres of wetland became disconnected from the creek around the Tideman-Johnson Park area (fig. 1). This disconnection may have been caused by a reduction in sediment supply and entrenchment rather than as a direct result of the fill. This also may have disconnected the creek from an even larger area of useable floodplain. In 1933, the Works Progress Administration (WPA) began excavating the channel of Johnson Creek to a depth of $15 \mathrm{ft}$, and hand-placed stone riprap on parts of the channel to protect against erosion. This work progressed from the mouth of the creek and went on upstream for almost $15 \mathrm{mi}$. Around Southeast (SE) 45th Street (fig. 1), the WPA also added a waterfall and a fish ladder designed for anadromous fish passage. 

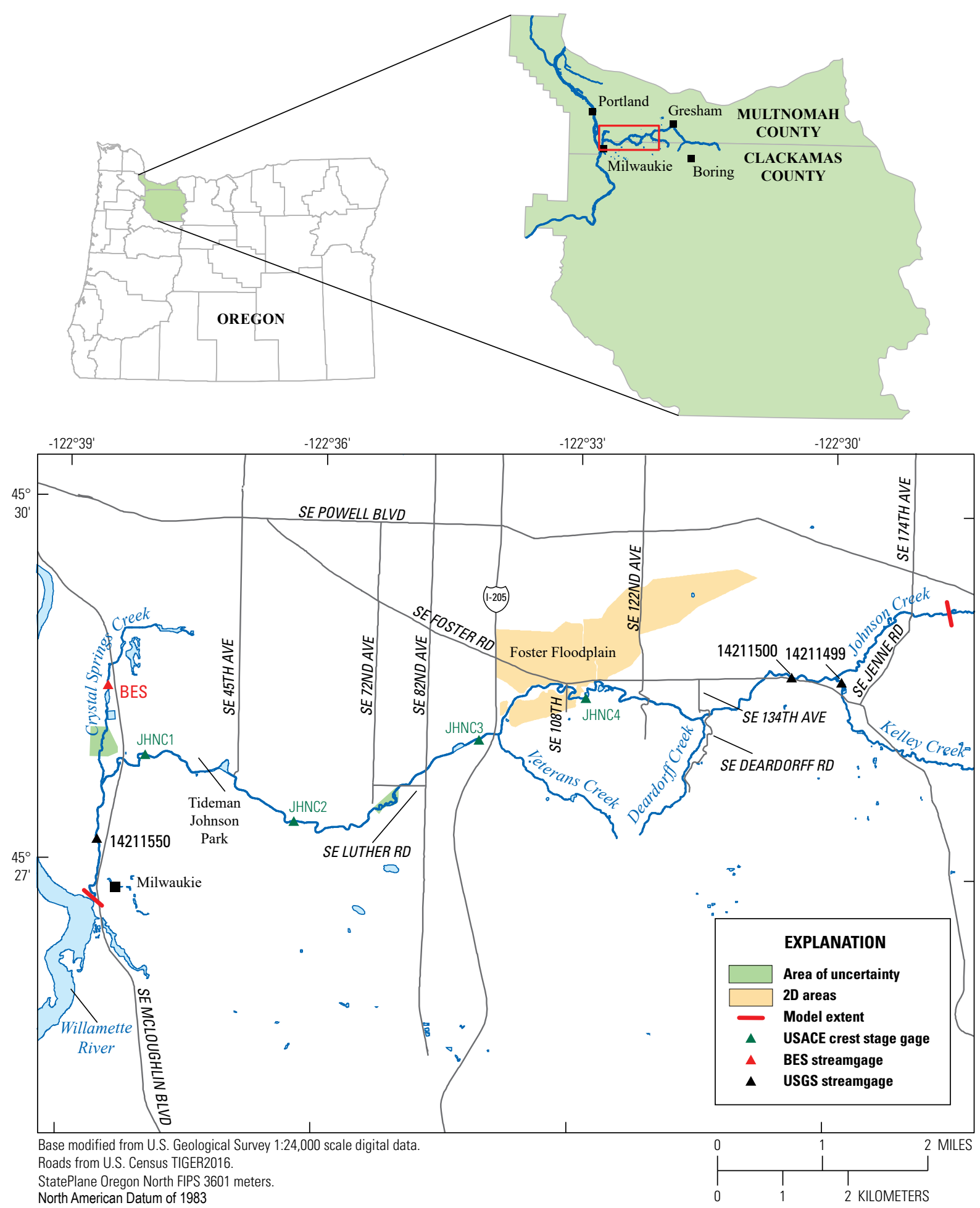

Figure 1. Location of study area, Johnson Creek watershed, near Portland, Oregon. (2D, two dimensional; BES, City of Portland Bureau of Environmental Services; USACE, U.S. Army Corp of Engineers; USGS, U.S. Geological Survey.) 
Recently, efforts have been made to restore Johnson Creek to more natural conditions. Some riprap has been removed from the channel walls. Other restoration efforts include work around SE Luther Road, where sinuosity was added to the creek, and vegetation and logs were added for bank stability. Around Tideman Johnson Park, trees and boulders were added to provide hydraulic grade control, and high-flow channels were connected for flood events.

The largest restoration effort to date took place around the Foster Floodplain, where over the course of 15 years the City of Portland purchased the land from more than 60 homeowners living within the 100 -year floodplain. This project removed homes and restored the creek over a one half-mile reach. More than 140 acre-ft of flood storage was added to the watershed, and three bridges were removed. The added flood storage is designed to accommodate a storm event as high as the 0.10 percent annual exceedance probability (AEP) (Gary Wolff, Otak, Inc, Portland, Oregon, oral commun., 2015).

Since the first USGS streamgage (hereinafter "gage") was installed in October 1940, the most significant floods that have occurred in Johnson Creek took place in December 2015, December 1964, November 1996, January 2009, and February 1996 (U.S. Geological Survey, 2016a). The December 2015 and January 2009 floods were more localized events, resulting from intensive rainfall rather than long durations of rainfall. The January 2009 event also had a rain-on-snow element. Although these floods were historical for Johnson Creek, they were not necessarily historical floods for larger watersheds in the region. The other three floods (December 1964, November 1996, and February 1996) were prolonged events and produced more regional historical flooding. Flooding tends to be most problematic around the Foster Floodplain where in the recent past, floods associated with stages above $11 \mathrm{ft}$ typically resulted in water reaching SE Foster Road and resulted in damage to nearby homes and businesses. Significant streamflow events also can cause flooding near Bell Station (around SE 72nd Avenue) and near the confluence with Crystal Springs Creek (fig. 1; Ali Young, City of Portland Bureau of Environmental Services, oral commun., 2016).

Prior to this study, local emergency managers and responders had several sources of information for responding to, managing, and alerting the public about flooding along Johnson Creek. One such source is the Northwest River Forecast Center (2016) hydrograph predictions for Johnson Creek, often referred to as the National Weather Service Advanced Hydrologic Prediction Service (AHPS). The AHPS Web site (https://www.nwrfc.noaa.gov/river/station/flowplot/ flowplot.cgi?lid=SYCO3) provides access to USGS data for streamflow and stage at the USGS streamgage Johnson Creek at Sycamore (14211500) and stage and streamflow 10-day forecasts. Predictions are made daily during periods of low or normal streamflow, but are made multiple times a day during large storm events. Although this Web site provides valuable information for those living and working near the gage, it becomes more difficult to estimate flooding effects farther away from the gage.

Another important source of flooding information is the Federal Emergency Management Agency Flood Insurance Study (FIS) for Portland (Federal Emergency Management Agency, 2010), which shows the 0.01 and 0.002 AEP floods for Johnson Creek and its largest tributaries. The FIS around Johnson Creek also was updated to account for the floodplain work around Foster Floodplain. Although these FIS maps are useful for floods of two specific AEPs, they are not as useful for floods between or less than the 0.01 and 0.002 AEP.

One method for alleviating informational gaps resulting from either streamflows not close to specific AEPs, or locations not near a streamgage with professionally forecasted hydrographs, is to produce a library of flood-inundation maps that are referenced to USGS streamgages. Maps associated with specific stages can be used by emergency responders to predict the severity of flooding at specific locations (such as roads and buildings). These maps can be used as a tool when constructing notification or evacuation plans. In addition, the maps provide an overall visual approximation to the extent of flooding and the estimated depth of water where flooding is likely to occur, which may help in communicating the severity of the flooding to the public and to government officials.

\section{Purpose and Scope}

This report describes the development of flood inundation maps used to estimate the extent of flooding along Johnson Creek from just upstream of SE 174th Avenue to the mouth (about 12.9 river miles). The report also details the development of the HEC-RAS model used to estimate longitudinal water-surface elevations associated with various streamflow levels.

All maps were produced for flood levels associated with USGS streamgage Johnson Creek at Sycamore (14211500), hereinafter referred to as the "Sycamore streamgage." The Sycamore streamgage is about $2 \mathrm{mi}$ from the upstream end of the study. The maps cover a range of 10-16 ft, in increments of $1 \mathrm{ft}$. Stages of 10, 11, and $14 \mathrm{ft}$ are designated as "action stage," "flood stage," and "major flood stage," respectively, by the National Weather Service.

Two other USGS streamgages were used in the development and calibration of the model. Near the mouth of Johnson Creek, at river mile 0.7, water levels and streamflow are checked against USGS streamgage Johnson Creek at Milwaukie (14211550), hereinafter referred to as "Milwaukie streamgage." Around river mile 11, streamflows from USGS streamgage Kelley Creek at 159th Drive, at Portland (14211499), hereinafter referred to as "Kelley Creek streamgage," were used to develop a lateral inflow hydrograph. 


\section{Study Area Description}

Johnson Creek is a tributary to the Willamette River, in northwestern Oregon. The headwaters of Johnson Creek originate in a rural/agricultural area east of the Portland metropolitan region near the town of Boring and generally flow westward, eventually passing through the city of Gresham and into Portland. In Portland, the creek crosses SE McLaughlin Boulevard then turns south and continues south to the mouth at Milwaukie at the confluence with the Willamette River. In general, the watershed becomes more urbanized closer to the mouth, although some tributaries are largely undeveloped.

The topographic drainage area at the mouth of Johnson Creek is $53.2 \mathrm{mi}^{2}$ (U.S. Geological Survey, 2016b). However, much of the precipitation that falls within the lower half of the basin is intercepted by stormwater infrastructure and does not enter the creek. The City of Portland Bureau of Environmental Services separated these areas of non-contribution within the watershed and calculated an "effective" drainage area for Johnson Creek at its mouth of around $35 \mathrm{mi}^{2}$. Unless stated otherwise, all references to the Johnson Creek watershed or any other watershed will refer to the topographical watershed rather than the effective watershed.

Northwestern Oregon has a temperate, Mediterranean climate characterized by mild, wet winters and warm, dry summers. Average annual precipitation in the Johnson Creek watershed is $52.7 \mathrm{in}$., and the maximum 24-hour 2-year precipitation intensity is 2 in. (U.S. Geological Survey, 2015). The watershed consists of about 27 percent forest, 1 percent wetlands, 10 percent developed open area, 27 percent low-intensity developed area, 25 percent medium-intensity developed area, 5 percent high-intensity developed area, and the remaining 5 percent categorized as "other." About 27 percent of the watershed is impervious (U.S. Geological Survey, 2015), although sumps in the area may result in an effective impervious area that is lower than this calculation (Greg Savage, City of Portland Bureau of Environmental Services, written commun., December 2016).

There are four significant tributaries in the study area (downstream of SE 174th Avenue), which for this study are defined as tributaries with drainage areas of $0.65 \mathrm{mi}^{2}$ or greater. Kelley Creek is the largest tributary in the study area, with a drainage area of $4.69 \mathrm{mi}^{2}$ at the USGS streamgage near the mouth. Deardorff and Veterans Creeks are much smaller at 0.78 and $0.67 \mathrm{mi}^{2}$, respectively. Crystal Springs Creek enters Johnson Creek downstream of McLoughlin Boulevard, and has a topographic drainage area of $4.39 \mathrm{mi}^{2}$, although its effective drainage area is much smaller. Crystal Springs Creek is unique among the four significant tributaries in that it is largely spring fed, and much of the precipitation that falls within its watershed is captured by the combined sewer system and sumps. Consequently, Crystal Springs Creek is largely unresponsive to all but very large precipitation events (Stonewall and Hess, 2016).
The study reach of Johnson Creek is about 12.9 river miles long and has at least 47 transportation crossings (road, railroad, light rail, streetcar, and footbridge crossings). There are four permanent streamgages in the study area, three of which are maintained by the USGS and one is maintained by the City of Portland Bureau of Environmental Services (BES; fig. 1). The Sycamore streamgage is within about $2 \mathrm{mi}$ of the upper boundary of the study area. Streamflow data have been continuously collected at the Sycamore streamgage since 1940. The Milwaukie streamgage is within $1 \mathrm{mi}$ of the mouth of Johnson Creek. Streamflow data have been collected there since 1989. Streamgages at the two largest tributaries in the study area, Kelley Creek streamgage and Crystal Springs Creek (BES streamgage) have been collected since 2000 and 2012, respectively. In addition to these streamgages, the U.S. Army Corp of Engineers (USACE) has a network of four crest-stage gages in the study reach (fig. 1). The USGS streamgage on Johnson Creek at Regner Road at Gresham, Oregon (14211400) (Regner streamgage) is upstream of the study reach, but was used for later analysis.

Most of the largest floods at the Sycamore streamgage have taken place during the last 21 years. Four of the five largest floods have been recorded since 1996 (table 1). Recent floods of interest include the flood of December 2015, which is the largest peak streamflow on record. The flood of January 2009 is the fourth-largest peak streamflow on record. Historically, the Foster Floodplain has been the most susceptible area to flooding in the study area (Portland Development Commission, 2013), although the completion of the Foster Floodplain Natural Area appears to have helped alleviate some of the flooding (East PDX News, 2012). Other areas affected by the December 2015 flood include near the confluence of Crystal Springs Creek (Oregonlive, 2015a, $2015 \mathrm{~b}$ ) just downstream of McLoughlin Boulevard and near 72nd Avenue, in an area referred to as "Bell Station" (Ali Young, City of Portland Bureau of Environmental Services, oral commun., 2016).

Table 1. Largest recorded floods at U.S. Geological Survey streamgage, Johnson Creek at Sycamore (14211500), Oregon.

[ $\mathrm{ft}^{3} / \mathrm{s}$, cubic foot per second]

\begin{tabular}{|c|c|c|c|}
\hline Date & Water year & $\begin{array}{c}\text { Streamflow } \\
\left(\mathrm{ft}^{3} / \mathrm{s}\right)\end{array}$ & $\begin{array}{c}\text { Stage } \\
\text { (in feet from } \\
\text { streamgage } \\
\text { datum) }\end{array}$ \\
\hline December 7, 2015 & 2016 & 2,740 & 15.33 \\
\hline December 22, 1964 & 1965 & 2,620 & 14.68 \\
\hline November 19, 1996 & 1997 & 2,550 & 15.30 \\
\hline January 2, 2009 & 2009 & 2,430 & 14.69 \\
\hline February 7, 1996 & 1996 & 2,350 & 14.28 \\
\hline December 13, 1977 & 1978 & 2,250 & 13.89 \\
\hline January 7, 1969 & 1969 & 2,220 & 12.29 \\
\hline January 12,1980 & 1980 & 2,210 & 14.03 \\
\hline November 24, 1960 & 1961 & 2,180 & 13.78 \\
\hline February 10, 1949 & 1949 & 2,110 & 13.77 \\
\hline
\end{tabular}




\section{Previous Studies}

Water-surface elevations associated with estimated 0.01 and 0.002 AEP streamflows were developed with the most recent flood insurance study (FIS) for Johnson Creek (Federal Emergency Management Agency, 2010). The flood-inundation coverages were developed using four separate HEC-RAS models, which were provided to the USGS for use in this study. The consulting firm Otak, Inc. (Otak), created a HECRAS model for use in and around the Foster Floodplain area, which was used to plan restoration efforts and design the flood storage infrastructure that was built in the area. This model was also provided to the USGS for use in this study. Stonewall and Hess (2016) evaluated the hydrology of Crystal Springs Creek, including calculating the 0.01 and 0.002 AEP streamflow values.

\section{Terminology}

Lateral inflow hydrograph.-A boundary condition hydrograph that enters the system between the upstream and downstream boundary conditions.

Normal depth.- The depth of flow when the slope of the water surface and channel bottom are the same and the water depth remains constant. In the U.S. Army Corps of Engineers Hydrologic Engineering Center's River Analysis System program (HEC-RAS; U.S. Army Corps of Engineers, 2016), a frictional slope (the loss of head along the length of the stream) is needed from the user to use normal depth as a downstream boundary condition.

Plan.-In HEC-RAS, a plan is a coupling of geometry and boundary conditions. In this study, a plan is "steady" or "unsteady" based on the boundary condition hydrographs. In the steady plans, the boundary condition hydrographs encompass the rising limb of the storm hydrograph up to a peak and then are held constant. This is not the conventional use of the term 'steady' for most HEC-RAS plans, but is a way of producing results that should be similar to those of a true steady model while still being able to incorporate two-dimensional (2-D) areas that are otherwise unusable in a true steady model. In the unsteady plans, the boundary condition hydrographs encompass both the rising and falling limb of the storm hydrograph.

Profile.-In HEC-RAS, a steady flow plan can have more than one profile. Each profile is associated with different values of streamflow. In unsteady plans, each time increment is represented by a profile.

River station (RS). - The distance in river feet from the mouth of Johnson Creek to the cross section. For example, RS 2148.391 is $2,148 \mathrm{ft}$ from the mouth of Johnson Creek along the path of the creek, not in a straight-line distance.

\section{Development of Flood-Inundation Map Library}

General USGS procedures for creating flood-inundation maps can be accessed at the Flood Inundation Mapping (FIM) program (U.S. Geological Survey, 2016c). Tasks specific to this project include:

1. Acquisition of recent hydraulic models in the Johnson Creek watershed,

2. Acquisition of geospatial data,

3. Development of a new hydraulic model,

4. Calibration of the model,

5. Computation of water-surface profiles,

6. Development of estimated flood-inundation maps,

7. Preparation of the maps for display on the USGS flood inundation mapping Web site.

\section{Model Development}

The HEC-RAS (version 5.0.0; U.S. Army Corps of Engineers, 2016) computer program was used to simulate a series of streamflows associated with specific gage heights at the Sycamore streamgage, and calculate water-surface elevations in Johnson Creek from just upstream of SE 174th Avenue to the mouth. The HEC-RAS software allows the user to perform either one-dimensional (1-D) steady flow hydraulics, 1-D and two-dimensional (2-D) unsteady flow river hydraulics, or other components of modeling not considered in this project (sediment transport, water temperature analysis, and generalized water quality modeling).

HEC-RAS can be run in either steady or unsteady mode. In steady mode, HEC-RAS models are simpler and more robust than models run in the unsteady mode. However, a steady version of a HEC-RAS model does not account for flood attenuation or storage. Historically, larger storm events tend to result in higher streamflow at Sycamore streamgage than at Milwaukie (fig. 2), whereas smaller storm events result in larger streamflow at Milwaukie. The combination of significant storage, demonstrated flood attenuation, and a lack of significant ungaged tributaries factored into the decision to use unsteady HEC-RAS plans to develop the flood-inundation maps.

The Johnson Creek model was created primarily as a 1-D model. However, for areas in and around the Foster Floodplain where overbank flow can travel significant distances, 2-D flow areas were developed, and connected to the 1-D portion of the model using lateral structures.

A complete list of flow plans used for calibration, model verification, flood-inundation map creation, and sensitivity analysis is provided in table 2 . 


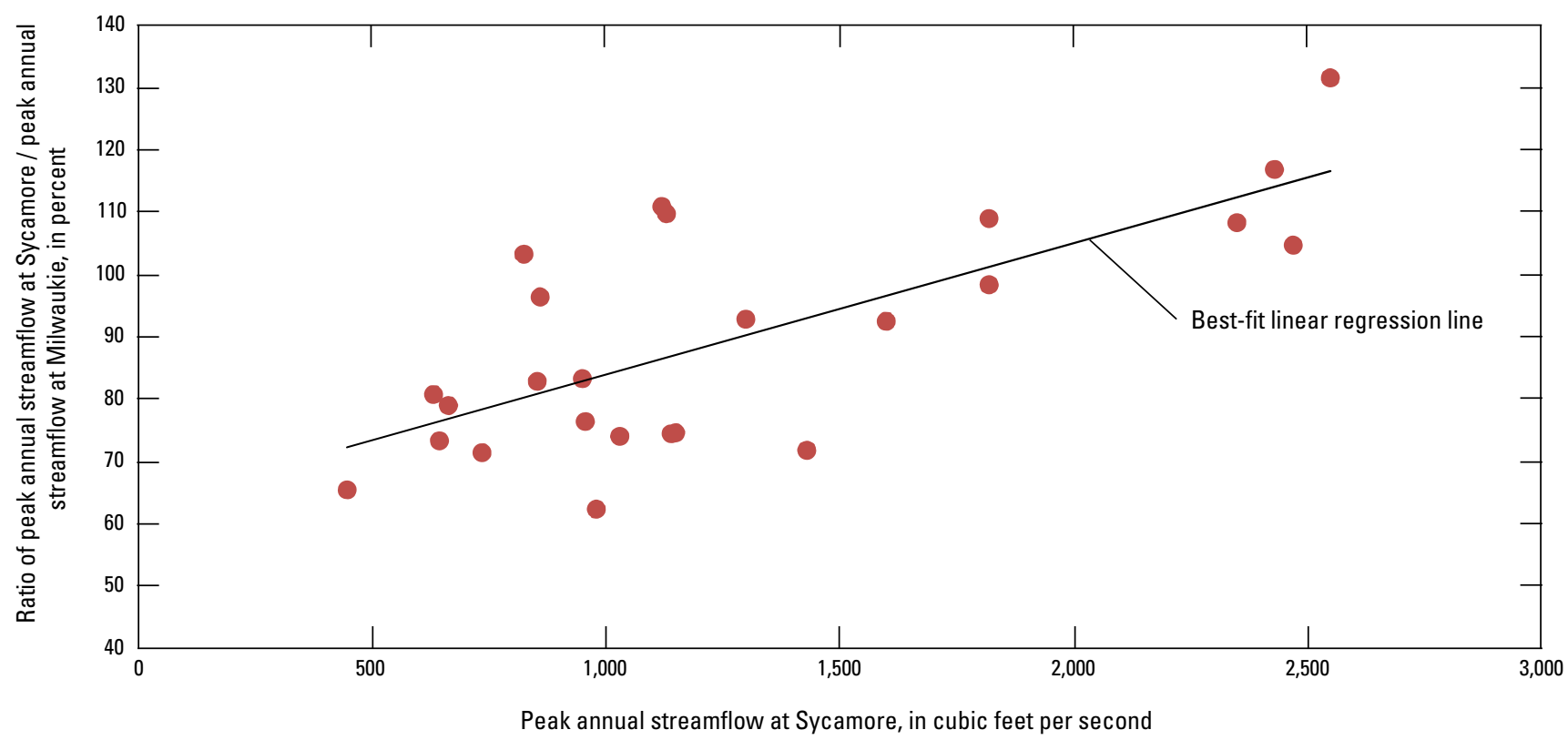

Figure 2. Relation between peak annual streamflow at U.S. Geological Survey streamgage on Johnson Creek at Sycamore (14211500) and ratio of peak annual streamflow at Sycamore streamgage to peak annual streamflow at Milwaukie streamgage (14211550), Johnson Creek, Oregon, water years 1990-2014.

Table 2. List of Hydrologic Engineering Center River Analysis System model plans for this study using U.S. Geological Survey streamgage on Johnson Creek at Sycamore (14211500), Oregon.

[ft, foot; FIM, flood-inundation map; SA, sensitivity analysis]

\begin{tabular}{|c|c|c|c|c|c|c|}
\hline Plan name & $\begin{array}{l}\text { Plan } \\
\text { type }\end{array}$ & $\begin{array}{c}\text { Stage at } \\
\text { Sycamore } \\
\text { streamgage }\end{array}$ & Purpose & Description & $\begin{array}{c}\text { Flood- } \\
\text { inundation } \\
\text { area } \\
\text { (acre) }\end{array}$ & $\begin{array}{c}\text { Maximum } \\
\text { depth on } \\
\text { Foster Road } \\
\text { (ft) }\end{array}$ \\
\hline Unsteady2015 & Unsteady & 15.33 & Calibration & Flood from December 2015 used for calibration & 415 & 2.26 \\
\hline Unsteady2009 & Unsteady & 14.69 & Check & Flood from January 2009 used to check calibration & 350 & 0.66 \\
\hline Unsteady_9ft_smooth & Unsteady & 9 & FIM & Used for best estimate of inundation in FIM & 100 & dry \\
\hline Unsteady_12ft_smooth & Unsteady & 12 & FIM & Used for best estimate of inundation in FIM & 174 & dry \\
\hline Unsteady_13ft_smooth & Unsteady & 13 & FIM & Used for best estimate of inundation in FIM & 219 & dry \\
\hline Unsteady_14ft_smooth & Unsteady & 14 & FIM & Used for best estimate of inundation in FIM & 290 & dry \\
\hline Unsteady_15ft_smooth & Unsteady & 15 & FIM & Used for best estimate of inundation in FIM & 375 & 1.90 \\
\hline Unsteady_16ft_smooth & Unsteady & 16 & FIM & Used for best estimate of inundation in FIM & 489 & 2.56 \\
\hline Steady $13 \mathrm{ft}$ smooth & Steady & 13 & FIM & Used for upper bound of uncertainty in FIM & 236 & dry \\
\hline Steady_14ft_smooth & Steady & 14 & FIM & Used for upper bound of uncertainty in FIM & 322 & dry \\
\hline Steady $15 \mathrm{ft}$ smooth & Steady & 15 & FIM & Used for upper bound of uncertainty in FIM & 450 & 2.36 \\
\hline Steady_16ft_smooth & Steady & 16 & FIM & Used for upper bound of uncertainty in FIM & 841 & 2.76 \\
\hline Unsteady_16ft_ext & Unsteady & 16 & SA & $\begin{array}{l}\text { Analysis of identical peak with more storm } \\
\text { volume }\end{array}$ & 547 & 2.65 \\
\hline Unsteady_16ft_cond & Unsteady & 16 & SA & $\begin{array}{l}\text { Analysis of identical peak with less storm } \\
\text { volume }\end{array}$ & 301 & dry \\
\hline Unsteady_16ft_Feb1996 & Unsteady & 16 & SA & $\begin{array}{l}\text { Analysis of identical peak with different } \\
\text { hydrograph shape }\end{array}$ & 468 & 2.56 \\
\hline
\end{tabular}




\section{Elevation Data}

The bare-earth digital elevation model (DEM) used for this study was acquired from the Oregon Department of Geology and Mineral Industries (written commun., June 4, 2015). The DEM was developed from the Oregon Lidar Consortium for the Portland metropolitan area study of 2014 (WSI, 2015). The bare-earth DEM represents the surface of the earth with all man-made structures and vegetation removed. The triangulated irregular network (TIN) processing of the ground point returns was used to derive the bare earth DEM from lidar data. The projection is Oregon Statewide Lambert Conformal Conic and the units are in international feet. The horizontal datum is NAD 83 (2011), and vertical datum is NAVD 88 (Geoid 12A). The DEM grid cell size is $3 \mathrm{ft}$. The vertical resolution of the data is $0.30 \mathrm{ft}$. Using table 1.2 from Dewberry (2016), this converts to an Equivalent Contour Accuracy of $1 \mathrm{ft}$.

The published datum of the Sycamore streamgage is at $228.47 \mathrm{ft}$ above National Geodetic Vertical Datum of 1929 , which converts to $231.84 \mathrm{ft}$ above NAVD 1988 using North American Vertical Datum Conversion (VERTCON; National Oceanographic and Atmospheric Administration, 2016). Stage values are checked against datum several times a year, and datum of bench marks and reference marks are checked through surveys every $1-3$ years (Kenney, 2010), and most recently on June 3, 2015.

Additional geospatial data were acquired by USGS field personnel during summer 2014, fall 2014, summer 2015, and fall 2015. Data were acquired using a Trimble ${ }^{\circledR}$ R8 GNSS System and a Trimble ${ }^{\circledR} 5600$ Total Station. All surveying was performed using Real-Time Network (RTN) surveying techniques with the Oregon Real-Time Global Navigation Satellite System network, or was geospatially tied to RTN-surveyed points using the Total Station. Most geospatial data, including new channel cross sections, were collected in areas of the watershed that had undergone significant restoration: the Foster Floodplain, Luther Road project, and the Schweitzer Phase of the East Powell Butte Restoration Project (City of Portland Bureau of Environmental Services, 2017). Other geospatial data were acquired to check against the previous models, to fill in data gaps or to confirm questionable data from previous models, especially around bridges and other crossings that were recently replaced or renovated. Acquired geospatial data were compared against lidar data and against benchmarks with published elevations (table 3). The root-mean squared error for all benchmarks was around $0.11 \mathrm{ft}$, which is within acceptable limits (Rydlund and Densmore, 2012).
Table 3. Acquired geospatial (surveyed) data compared against published City of Portland, Oregon benchmarks.

[ft, foot; NAVD 88, North American Vertical Datum of 1988; RMSE, root-mean square error]

\begin{tabular}{rrrr}
\hline $\begin{array}{c}\text { City of Portland } \\
\text { benchmark No. }\end{array}$ & $\begin{array}{c}\text { Published } \\
\text { elevation } \\
\text { (ft above } \\
\text { NAVD 88) }\end{array}$ & $\begin{array}{l}\text { Surveyed } \\
\text { elevation } \\
\text { (ft above } \\
\text { NAVD 88) }\end{array}$ & $\begin{array}{c}\text { Elevation } \\
\text { difference } \\
\text { (ft) }\end{array}$ \\
\hline 90 & 248.849 & 248.998 & 0.149 \\
1315 & 263.237 & 263.187 & -0.050 \\
2387 & 211.049 & 210.885 & -0.164 \\
2389 & 217.809 & 217.830 & 0.021 \\
2558 & 134.890 & 134.890 & 0.000 \\
3186 & 212.268 & 212.103 & -0.165 \\
3516 & 343.620 & 343.620 & 0.000 \\
3518 & 376.560 & 376.439 & -0.121 \\
& & Average: & -0.04 \\
& & Maximum: & 0.15 \\
& & Minimum: & -0.16 \\
& & RMSE: & 0.11 \\
\hline
\end{tabular}

\section{Model Geometry}

The base of the model geometry was developed using existing Flood Insurance Study models from the USACE and the private consulting firm Otak. The USACE project consisted of four steady HEC-RAS models: (1) from the mouth of Johnson Creek to river mile 3.46, (2) from river mile 3.46 to 6.55 , (3) from river mile 6.55 to 9.96 , and (4) from river mile 9.96 to 12.89 . The Otak project focused on the changes to the Foster Floodplain area, from near Interstate 205 to about SE 122nd Avenue. The Otak HEC-RAS model was run in the unsteady mode.

The four USACE and one Otak HEC-RAS model geometries were combined into one geometry file. In the areas where the models overlapped, the newer Otak geometry file replaced any geometry data from the older USACE file.

HEC-GeoRAS software (U.S. Army Corps of Engineers, 2016) is a set of procedures, tools, and utilities to process HECRAS output in ArcGIS (ESRI ${ }^{\circledR}$, Redlands, California). HECGeo-RAS can be used to prepare geometric data for import into HEC-RAS, and to process streamflow simulation results exported from HEC-RAS. HEC-Geo-RAS and the lidar data were used to extract cross sections from the DEM grid and to project stream elevations onto the land surface.

The geometry file created for the HEC-RAS model consists of 713 cross sections, about 300 of which were created through the HEC-RAS interpolation tool. Interpolated cross sections were needed primarily in areas with high channel slopes (for example 
near SE Luther Road) and in areas where the previous model contained sparse geospatial data (for example, around Deardorff Road). Two hundred fifty-six (256) cross sections were imported from the previous FIS HEC-RAS models, although an unknown number of these were replaced either with cross sections from the Otak model or with cross sections collected more recently by USGS personnel. One hundred twenty-eight (128) cross sections were imported from the Otak model; only a few were replaced by more recent USGS survey data. Forty-two (42) cross sections were surveyed for this study, including 8 cross sections that served as checks against the geometry files from the previous FIS HEC-RAS models. Geospatial data collected for this study generally checked well against the older geometry files. Cross sections surveyed by the USGS were presumed to have levels of accuracy similar to established benchmarks surveyed (table 3). The accuracy of geospatial data collected for the cross sections used in the FIS and Otak models is unknown, but presumed to be of similar accuracy based on the checks performed by USGS.

Four 2-D flow areas were developed for the model, all of which were within close proximity of the Foster Floodplain. The 2-D flow areas were developed to model streamflow that occurs out of bank in the area. These areas replaced storage areas created in the Otak model and were connected to the main channel using lateral weirs.

\section{Boundary Conditions}

Annual peak streamflow and instantaneous values of streamflow for the Sycamore streamgage are available from the National Water Information System (NWIS; U.S. Geological Survey. 2016d). Stage data are referenced to a local datum, but are converted to the North American Vertical Datum of 1988 by adding $231.84 \mathrm{ft}$.

The model was calibrated using the December 2015 flood, which was the largest streamflow event since record keeping began in October 1940. The upstream boundary condition for the 2015 flow file was the streamflow hydrograph at the Sycamore streamgage, minus the lateral inflow at Kelley Creek. In addition, the hydrograph was pushed forward 2 hours to account for the time of travel between the upper portion of the model and location of the Sycamore streamgage. The 2-hour lag was calculated using the average cross-section velocity near the peak, and corroborated by visual inspection of the output hydrographs.

The downstream boundary condition was a normal depth using a slope of 0.004 . This slope was calculated using the average slope between the downstream cross sections of the creek (RS 347.1-50.6 ft). Modeled water-surface elevations were not tied to the water-surface elevations from the Johnson Creek/Willamette River FIS model currently in effect.

Lateral inflows were developed for Kelley Creek, Deardorff Creek, Veterans Creek, and Crystal Springs Creek. The sum of the drainage areas of all three lateral inflows that enter downstream of the Sycamore streamgage plus the drainage area at the Sycamore streamgage is $32.6 \mathrm{mi}^{2}$. For comparison, effective drainage area at the mouth of Johnson Creek is about $35 \mathrm{mi}^{2}$. Using this number, the upstream boundary condition and lateral inflows account for 93 percent of the drainage area at the mouth. However, some of the drainage areas for these lateral inflows might also contain areas where precipitation is intercepted by the stormwater system, especially in the more urban tributaries such as Crystal Springs Creek.

The lateral inflow hydrograph at Kelley Creek was developed primarily using data from the streamgage. However, because of a streamgage malfunction, streamflow values were not available during the peak at Kelley Creek. Two hydrographs for Kelley Creek were estimated by logarithmic regression analysis. One logarithmic regression analysis was performed using streamflow data from the Sycamore streamgage, which is close geographically but has a drainage area over five times larger than Kelley Creek. The other logarithmic regression analysis was performed using streamflow data from the Regner streamgage, which has a contributing drainage area about three times larger than Kelley Creek, but is farther from the Kelley Creek streamgage than the Sycamore streamgage. The Sycamore streamgage regression tended to underpredict the rising and peak values of flood hydrographs, whereas the Regner streamgage regression tended to overpredict. The resultant hydrographs were then averaged into one hydrograph, which predicted a peak at Kelley Creek streamgage of $667 \mathrm{ft}^{3} / \mathrm{s}$.

As a check against this calculation, the peak streamflow of the resulting December 2015 hydrograph was compared to the history of peak streamflow at the Sycamore streamgage as follows. A linear regression analysis was developed using only peak annual streamflows from Sycamore and Kelley Creek streamgages (the previous regressions had used daily streamflow values). Goodness-of-fit tests showed a strong correlation $\left(\mathrm{r}^{2}=0.94\right)$ and low errors (mean error of 1 percent and mean absolute error of 13 percent) for a peak flow regression (fig. 3). The estimated peak flow at Kelley Creek for the December 2015 flood using this regression was $689 \mathrm{ft}^{3} / \mathrm{s}$, which checks well against the hydrograph created using the averaged regressions of all Sycamore and Regner streamflow data $\left(667 \mathrm{ft}^{3} / \mathrm{s}\right)$.

Lateral inflows were created for Deardorff Creek by multiplying the Kelley Creek hydrograph by the ratio of drainage areas between Deardorff Creek $\left(0.78 \mathrm{mi}^{2}\right)$ and Kelley Creek $\left(4.69 \mathrm{mi}^{2}\right)$. The same method was used to create the lateral inflows for Veterans Creek $\left(0.67 \mathrm{mi}^{2}\right)$. Streamflow values for the lateral inflow of Crystal Springs Creek, which is predominantly fed by groundwater springs and only responds to large precipitation events (Stonewall and Hess, 2016), were provided by the City of Portland Bureau of Environmental Services from the streamgage they operate. 


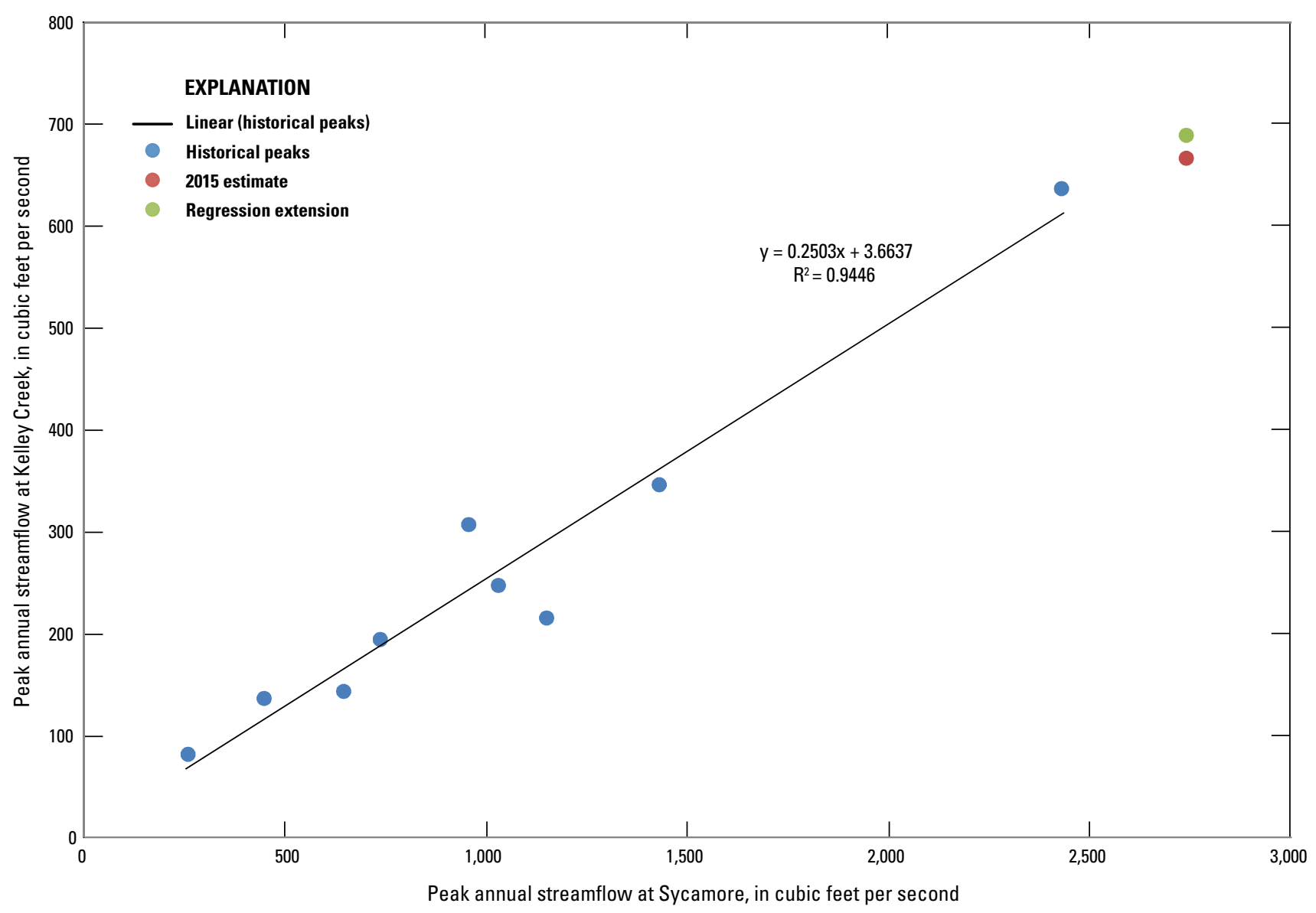

Figure 3. Relation between peak annual streamflow at U.S. Geological Survey streamgages on Johnson Creek at Sycamore (14211500) and Kelley Creek at SE 159th Drive at Portland, Oregon (14211499), Oregon, water years 2001-14.

Boundary condition hydrographs for the HEC-RAS plans used to model specific stages at the Sycamore streamgage were identical in shape to the December 2015 flood event, but were scaled up or down to produce the correct amount of streamflow. For example, plan "Unsteady_10ft_smooth" is used to model an unsteady storm with a peak stage at Sycamore of $10 \mathrm{ft}$. The term "smooth" reflects a model design choice made to 'smooth out' the Kelley Creek hydrographs by interpolating from 15-minute time increments down to 1-minute time increments in order to add model stability. This process was applied to each plan, although the name 'smooth' does not appear on each plan. This naming convention was kept in order to be consistent with model archives.

\section{Model Calibration}

The HEC-RAS model was primarily calibrated by adjusting Manning's roughness coefficients. Stream channel

${ }^{1}$ The Theta coefficient is the "Theta Implicit Weighing Factor" used for weighing the spatial derivative used in solving the finite difference forms of the St. Venant equations. roughness coefficients ranged from 0.02 to 0.065 , and overbank roughness coefficients ranged from 0.03 to 0.1 . The lowest overbank coefficients were placed in areas with large amounts of open fields or paved surfaces, whereas the highest coefficients were used for densely wooded areas. The relatively large range in channel roughness coefficients is indicative of the wide variety of channels present in the creek, from heavily wooded, relatively natural areas, to channel sections lined with cement or stone from historical channel modification. Initial channel roughness coefficients were taken from the FIS and Otak models, and altered as needed for calibration. Other calibration techniques included adding or altering ineffective flow areas, altering lateral weir coefficients used to connect storage areas and adjusting the Theta coefficient used in unsteady flow calculations ${ }^{1}$.

Model output was compared against recorded stage and associated streamflow records at Sycamore and Milwaukie streamgages. In addition, model output also was compared against elevations determined from crest stage gages and other high water marks. 
After the initial model runs, results were assessed for accuracy (for example, how closely did results approximate recorded high water marks, and how closely did the rating curve at the cross section nearest the Sycamore streamgage approximate the stage-discharge relation at the gage) and validity (for example, does the energy grade decrease with distance downstream). For assessment of accuracy, the most weight was given to the recorded stage and streamflow values at the Sycamore and Milwaukie streamgages. Any critical water-surface calculations were addressed, usually by rechecking previous assumptions made with regard to Manning's roughness coefficients or ineffective flow areas.

Inundation areas were calculated for all model plans (table 2). Inundation areas were not corrected for small areas of ineffective flow that were not hydraulically connected to Johnson Creek, so overall estimates of inundation will be biased high. However, the relative scale of inundation allows for direct comparison between plans.

In addition, a transect line was drawn across SE Foster Road just west of SE 110th Drive (fig. 4A). This location was selected because SE Foster Road has historically had standing water during high flows, and if the road is closed, it can affect nearby neighborhoods and businesses. The transect was drawn at a relatively low point, and was used to find the deepest pool of water for a given flood plan (table 2). The deepest portion of the transect was always at the southern end of the line, near where the curb meets the sidewalk (example in fig. $4 B$ ).
Eight debris high-water marks, four crest-stage gage (CSG) readings and two recorded stages and streamgages from the flood of December 2015 were compared to modeled values (table 4). The average difference between modeled and measured elevations was $+0.13 \mathrm{ft}$, with maximum and minimum differences of +1.06 and $-1.19 \mathrm{ft}$, respectively. Of the 14 water-surface elevations recorded or measured, 10 were within $\pm 0.6 \mathrm{ft}$. Of the four water-surface elevations with greater differences between modeled and measured or recorded values, all were either recorded CSG readings or observed debris lines.

The modeled peak stage at the Sycamore streamgage was within $0.47 \mathrm{ft}$ of recorded peak value, and the shape and timing of the modeled and recorded hydrographs were consistent (fig. 5). The modeled peak stage at the Milwaukie streamgage was within $0.12 \mathrm{ft}$ of recorded peak stage, but the shape and timing of the hydrograph were not as close (fig. 6). Several approaches were used to attempt to reshape the modeled Milwaukie hydrograph to something closer to measured values, including the manipulation of Manning's $n$ values, the addition of more storage, and adding additional tributaries. None of the approaches used resulted in significant improvement, and most produced other problems when implemented, such as too much water volume in the hydrograph or peak water-surface elevations that were too high. The modeled total storm volume was close to measured values at both streamgages $(+0.31$ percent at Sycamore and -1.47 percent at Milwaukie).

Table 4. Comparison of modeled and measured high water marks for flood event at Johnson Creek, Oregon, December 2015.

[CSG, crest-stage gage; ft, foot, HWM, high-water mark; NAVD 88, North American Vertical Datum of 1988; RMSE, root-mean squared error]

\begin{tabular}{cllcr}
\hline $\begin{array}{c}\text { Location } \\
\text { (river station) }\end{array}$ & $\begin{array}{c}\text { Type of } \\
\text { HWM }\end{array}$ & $\begin{array}{c}\text { Measured } \\
\text { (ft above } \\
\text { NAVD 88) }\end{array}$ & $\begin{array}{c}\text { Modeled } \\
\text { (ft above } \\
\text { NAVD 88) }\end{array}$ & $\begin{array}{c}\text { Elevation } \\
\text { difference } \\
\text { (ft) }\end{array}$ \\
\hline 63234 & measured & 252.9 & 251.71 & -1.19 \\
63053 & measured & 250.94 & 250.96 & 0.02 \\
57287 & streamgage & 247.17 & 246.7 & -0.47 \\
51868 & measured & 233.56 & 233.65 & 0.09 \\
42769 & CSG & 216.15 & 216.18 & 0.03 \\
39076 & measured & 210.72 & 210.48 & -0.24 \\
34325 & measured & 200.49 & 200.54 & 0.05 \\
33835 & CSG & 199.43 & 200.37 & 0.94 \\
28089 & measured & 181.8 & 181.23 & -0.57 \\
20819 & CSG & 131.11 & 132.04 & 0.93 \\
16694 & measured & 104.86 & 105.35 & 0.49 \\
10380 & CSG & 68.71 & 69.25 & 0.54 \\
8224 & measured & 56.24 & 57.30 & 1.06 \\
3690 & streamgage & 34.72 & & 34.84 \\
& & & Average: & 0.12 \\
& & Maximum: & 0.13 \\
& & & Minimum: & 1.06 \\
& & & RMSE: & -1.19 \\
\hline
\end{tabular}



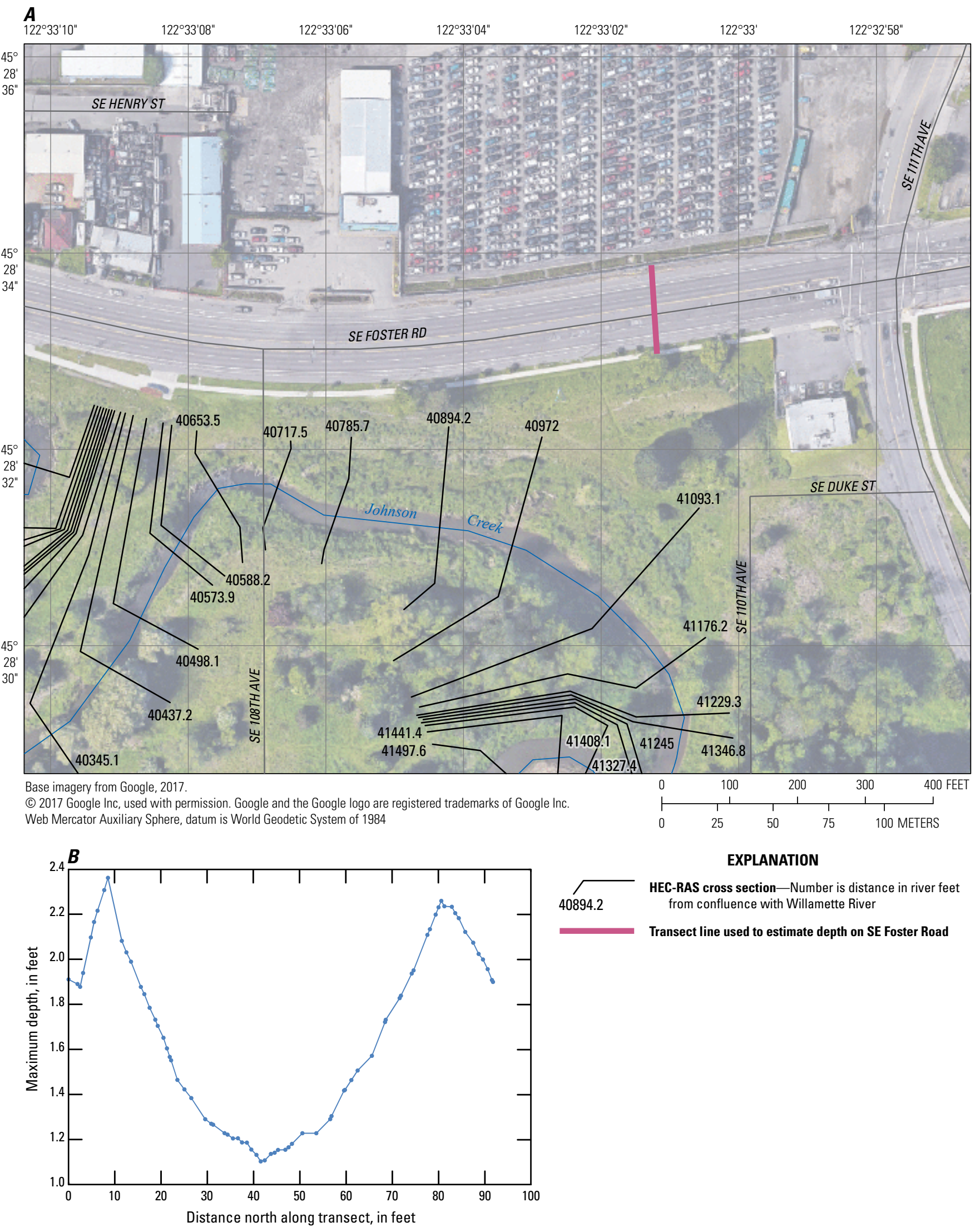

HEC-RAS cross section-Number is distance in river feet from confluence with Willamette River

Transect line used to estimate depth on SE Foster Road

Figure 4. Position of the profile line used to estimate maximum depth on SE Foster Road $(A)$, and example of a Hydrologic Engineering Center River Analysis System (HEC-RAS) profile output for model plan Steady_15ft_smooth (B), Johnson Creek, Oregon. 

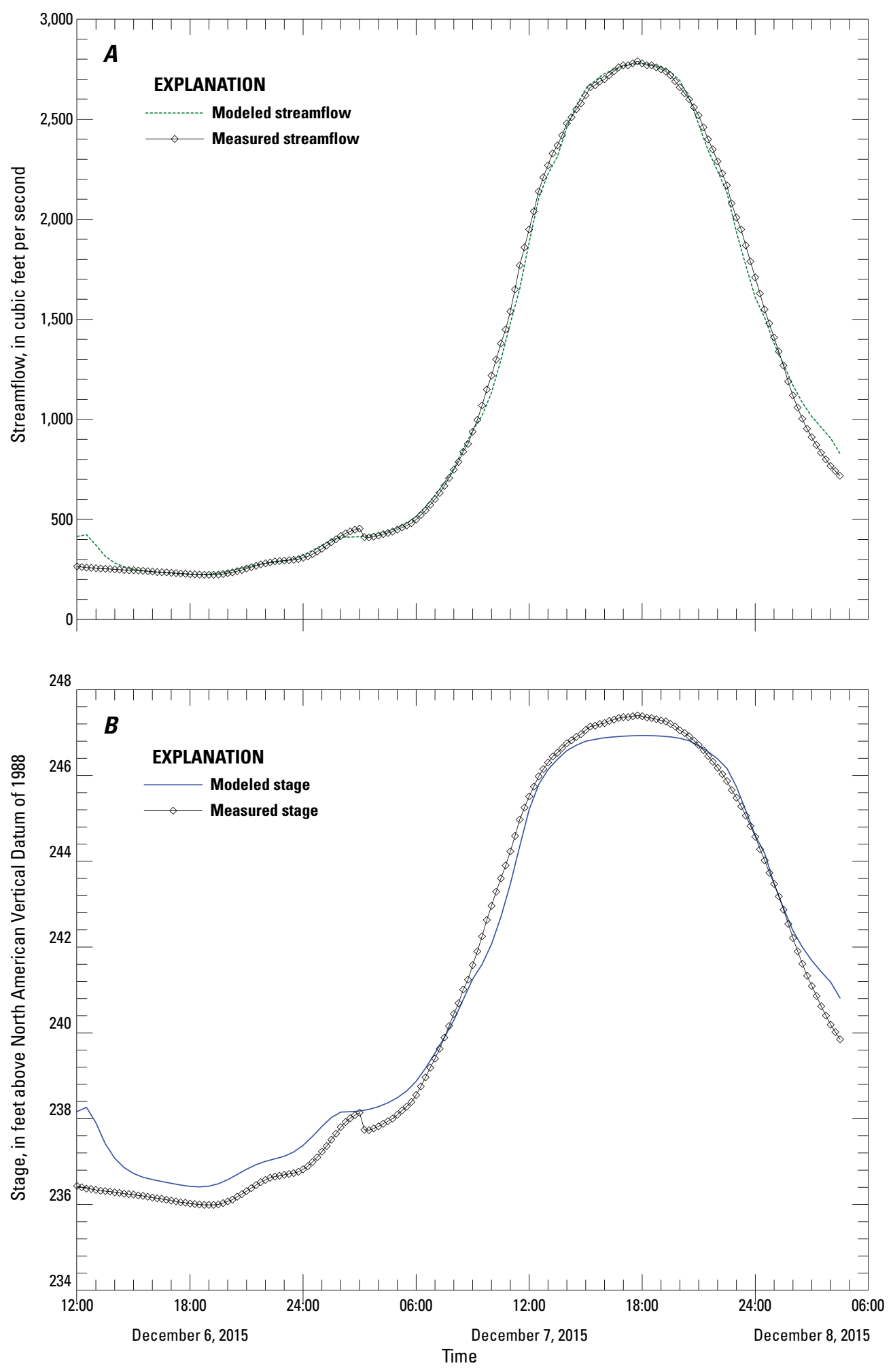

Figure 5. Relation between modeled and measured streamflow $(A)$ and stage $(B)$ at the U.S. Geological Survey streamgage on Johnson Creek at Sycamore (14211500; River Station 57287.5) during flood event, Johnson Creek, Oregon, December 2015. Based on Hydrologic Engineering Center River Analysis System model output for plan Unsteady2015. 

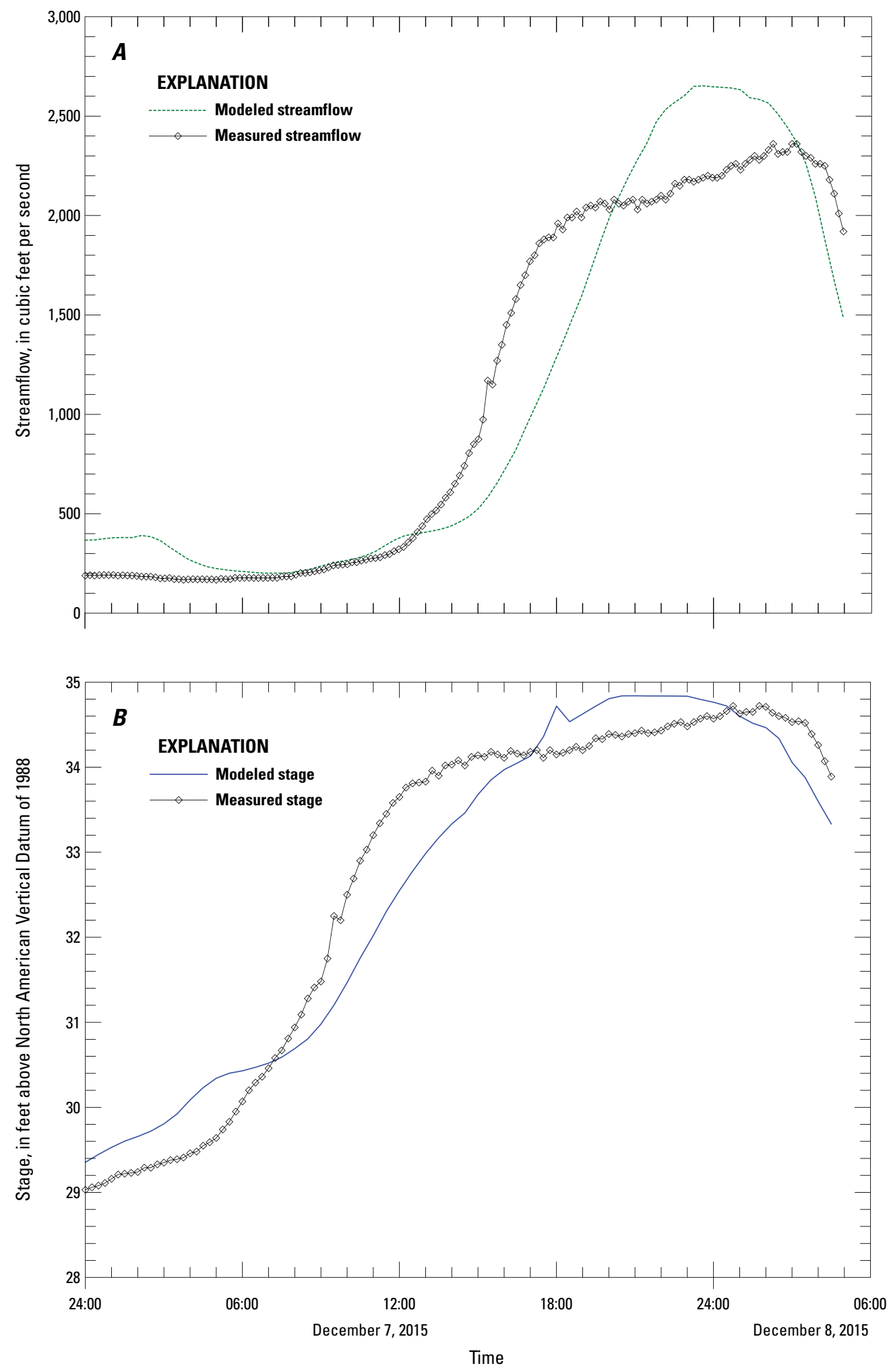

Figure 6. Relation between modeled and measured streamflow $(A)$ and stage $(B)$ at the U.S. Geological Survey streamgages on Johnson Creek at Milwaukie (14211550; River Station 3690.7) during flood event, Johnson Creek, Oregon, December 2015. Based on Hydrologic Engineering Center River Analysis System model output for plan Unsteady2015. 
The model was checked using data from the January 2009 event, which was the fourth-highest recorded peak at the Sycamore streamgage for the period of record (water years 1941-2016). Identical sources were used for the streamflow inputs for the 2009 model run except for Crystal Springs Creek and Kelley Creek. For Kelley Creek, no streamflow data were missing so there was no need to estimate streamflows. The Crystal Springs Creek streamgage was not installed until after 2009, so streamflow data were estimated using the techniques outlined in Stonewall (2014).

The only high water marks available from the January 2009 event were the two recorded peaks at the Sycamore and Milwaukie streamgages, and three CSG peaks. Four CSGs were installed at the time of the January 2009 event, but one (RS 33835, JHNC 3 in fig. 1) appeared to have no mark. It is unknown whether the lack of a mark was caused by the water not being high enough to leave a mark or if the vents in the CSG were plugged, which would not allow for water to enter the pipe and leave a mark. The CSG at RS 33835 was ignored for the purposes of this analysis.

The average difference between the modeled and measured high water marks for the January 2009 event was $0.26 \mathrm{ft}$, with a maximum of $1.17 \mathrm{ft}$ and a minimum of $-0.91 \mathrm{ft}$ (table 5). The two recording streamgages at Sycamore and Milwaukie (RS 57287 and 3690, respectively) showed greater agreement than the CSGs. This was expected as CSGs are typically located close to bridges where large jumps in hydraulic head occur, making accurate modeling more difficult.

In general, differences between modeled and measured elevations were of the same direction. Specifically, if at a particular location the model predicted a lower water-surface elevation than what was measured in December 2015, the same location showed a lower water-surface elevation than what was measured in the January 2009 event. The lone exceptions were the CSG readings at RS 42769, where the 2015 model accurately predicted the CSG mark $(+0.03 \mathrm{ft}$; table 4), but the 2009 model predicted a lower watersurface elevation than what was measured (-0.91 ft; table 5). This was expected, because RS 42769 is near the Foster Floodplain where restoration efforts resulted in significant changes to the channel. The new channel configuration results in much more water overflowing the left bank and into a designed storage area. Consequently, water-surface elevations should be lower at this CSG and surrounding area. Because the 2009 model was run using the 2015 channel geometry, it was expected that modeled water-surface elevations would be lower than those measured in 2009. This theory also is supported by the flooding observed in the neighborhood north of SE Foster Road. In 2015, less flooding was observed in the neighborhood than the flooding that occurred in 2009 (Maggie Skendarian, City of Portland Bureau of Environmental Services, oral commun., 2016), despite more water passing through the Sycamore streamgage in 2015 than in 2009.

The modeled hydrograph at Sycamore compared well with the measured hydrograph (fig. 7). The modeled peak was within $0.07 \mathrm{ft}$ of the measured peak, and the total storm volume was within 0.35 percent. The modeled hydrograph at Milwaukie for the January 2009 deviated from the measured hydrograph in ways that were analogous to the 2015 model (fig. 8). The model once again showed a narrower peak than the broader peak measured at the streamgage. The modeled peak stage was within $0.34 \mathrm{ft}$ of the measured value, and the total storm volume was within 7.45 percent.

Table 5. Comparison of modeled and measured high water marks for flood event, Johnson Creek, Oregon, January 2009.

[CSG, crest-stage gage; ft, foot; HWM, high-water mark; NAVD 88, North American Vertical Datum of 1988; RMSE, root-mean squared error]

\begin{tabular}{|c|c|c|c|c|}
\hline $\begin{array}{c}\text { Location } \\
\text { (river station) }\end{array}$ & $\begin{array}{l}\text { Type of } \\
\text { HWM }\end{array}$ & $\begin{array}{c}\text { Measured } \\
\text { (ft above } \\
\text { NAVD 88) }\end{array}$ & $\begin{array}{l}\text { Modeled } \\
\text { (ft above } \\
\text { NAVD 88) }\end{array}$ & $\begin{array}{c}\text { Elevation } \\
\text { difference } \\
\text { (feet) }\end{array}$ \\
\hline 57287 & gage & 246.53 & 246.46 & -0.07 \\
\hline 42769 & $\mathrm{CSG}$ & 216.70 & 215.79 & -0.91 \\
\hline 33835 & $\mathrm{CSG}$ & No mark ${ }^{1}$ & 200.16 & $\mathrm{n} / \mathrm{a}$ \\
\hline 20819 & $\mathrm{CSG}$ & 130.64 & 131.81 & 1.17 \\
\hline 10380 & $\mathrm{CSG}$ & 68.24 & 69.01 & 0.77 \\
\hline 3690 & gage & 34.25 & 34.59 & 0.34 \\
\hline & & \multicolumn{2}{|c|}{$\begin{array}{l}\text { Average: } \\
\text { Maximum: } \\
\text { Minimum: } \\
\text { RMSE: }\end{array}$} & $\begin{array}{r}0.26 \\
1.17 \\
-0.91 \\
0.76\end{array}$ \\
\hline
\end{tabular}

\footnotetext{
${ }^{1}$ Although there was no discernible mark left on the CSG, the elevation of the pin is $199.00 \mathrm{ft}$. This suggests that either the water did not reach this elevation, or that the CSG had become plugged and was not allowing water inside to leave a mark.
} 

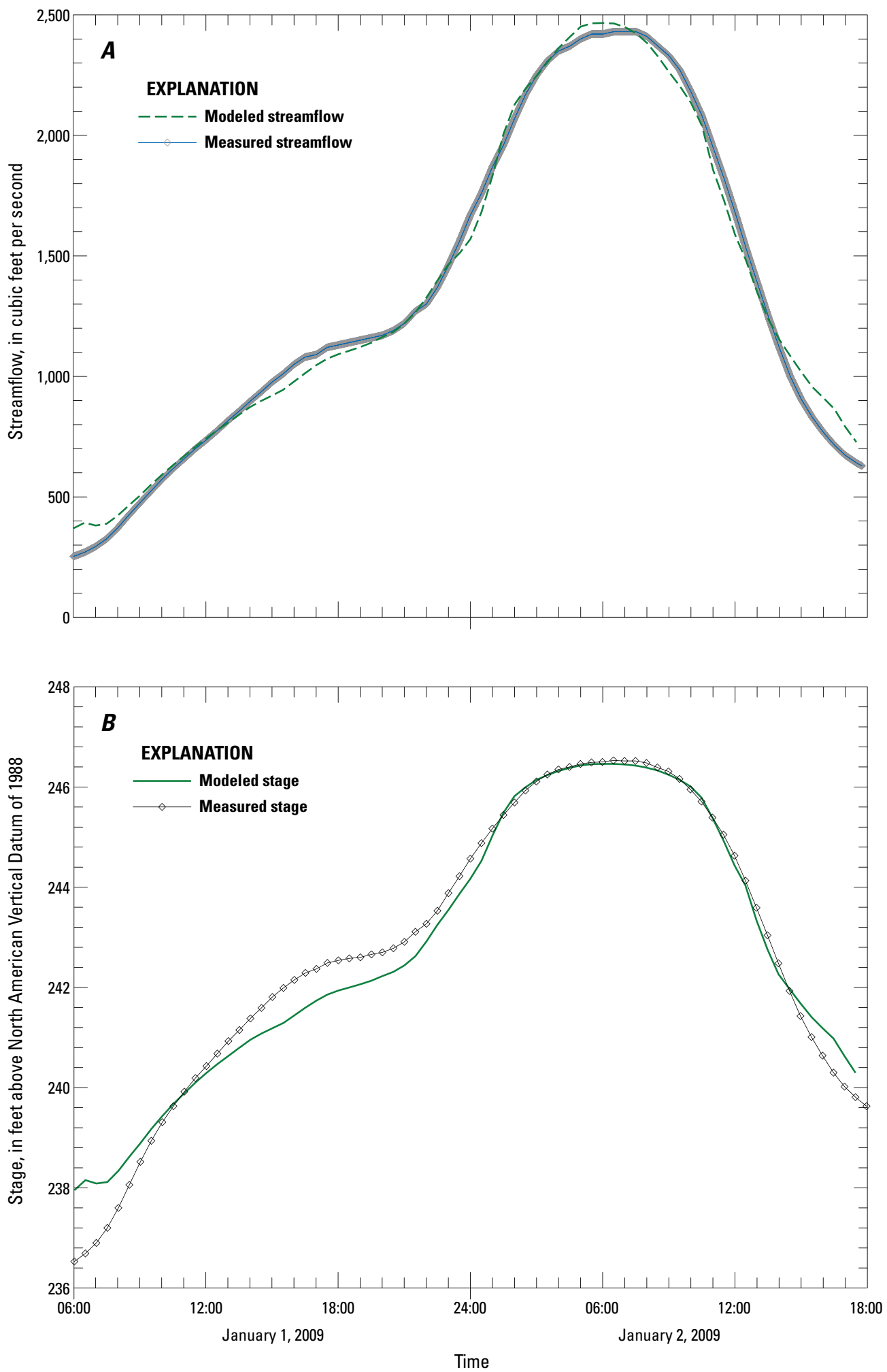

Figure 7. Relation between modeled and measured streamflow $(A)$ and stage $(B)$ at the U.S. Geological Survey streamgage on Johnson Creek at Sycamore (14211500; River Station 57287.5) during flood event, Johnson Creek, Oregon, January 2009. Based on Hydrologic Engineering Center River Analysis System model output for plan Unsteady2009. 

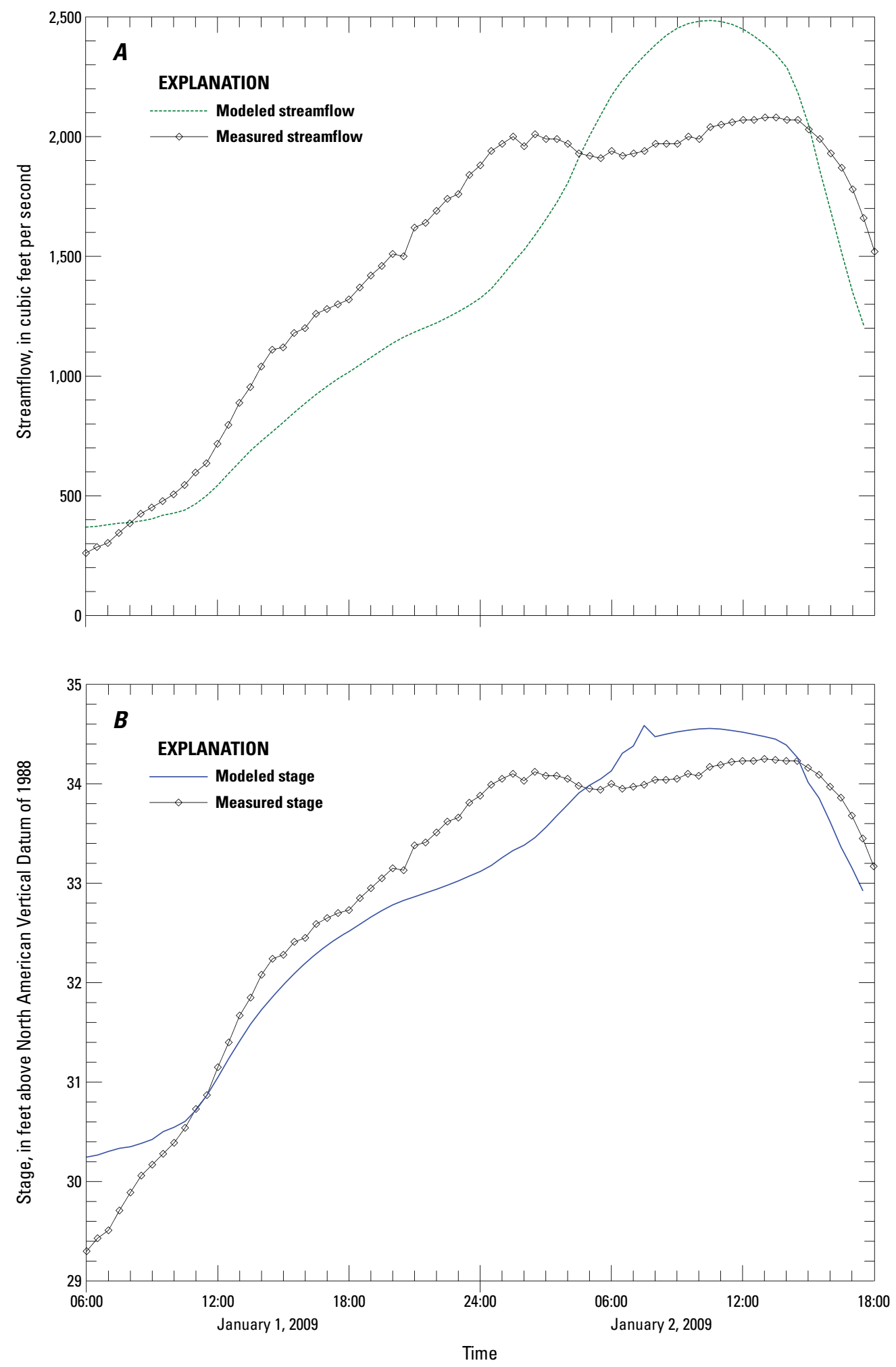

Figure 8. Relation between modeled and measured streamflow $(A)$ and stage $(B)$ at the U.S. Geological Survey streamgage on Johnson Creek at Milwaukie (14211550; River Station 3690.7) flood event, Johnson Creek, Oregon, January 2009. Based on Hydrologic Engineering Center River Analysis System model output for plan Unsteady2009. 


\section{Sensitivity Analysis}

To evaluate effects of specific decisions made during model creation, the following sensitivity analyses were performed:

1. Evaluation of hydrograph shape.

2. Assumption of more volume for the same peak streamflow.

3. Assumption of less volume for the same peak streamflow.

4. Maximum flood inundation for a given stage.

All plans used for the sensitivity analyses assumed the maximum stage of the Sycamore streamgage rating (16 ft). This stage was selected to maximize the differences between models without requiring an extension of the current rating. The selected stage is higher than the maximum stage measured since records began in October 1940. Because all sensitivity analysis plans have the same peak flow, differences seen in depth and flood-inundation area can be ascribed solely to the timing and shape of the hydrographs used rather than based on differences in the peak streamflows. The amount of scaling needed for the upstream boundary condition and for the Kelley Creek lateral inflow to reach $16 \mathrm{ft}$ of stage at Sycamore was determined, then each other lateral inflow was scaled using the same factor. The timing of lateral inflow hydrographs was not changed.

The influence of hydrograph shape was analyzed by comparing plan Unsteady_16ft_smooth to plan Unsteady_16ft_Feb1996. The latter plan was developed by scaling the flood event of February 1996 to a stage at Sycamore of $16 \mathrm{ft}$. Among the five largest floods recorded at the Sycamore streamgage, the flood of February 1996 subjectively appears to be the most disparate from the others (fig. 9). Whereas the hydrographs of the other floods in figure 9 are largely defined by one predominant peak, the February 1996 flood has two peaks of similar magnitude, which were preceded by a third, smaller but still significant peak that occurred about 1.5 days before the largest peak.

Because the Kelley Creek and Crystal Springs Creek streamgages were not active in 1996, streamflow values were estimated for both lateral inflows. Kelley Creek streamflow values were estimated using a logarithmic regression equation with the Sycamore streamgage. (The Regner streamgage also was not active in 1996.) Streamflow from Crystal Springs Creek was estimated using the technique outlined in Stonewall (2014) (also a regression equation).

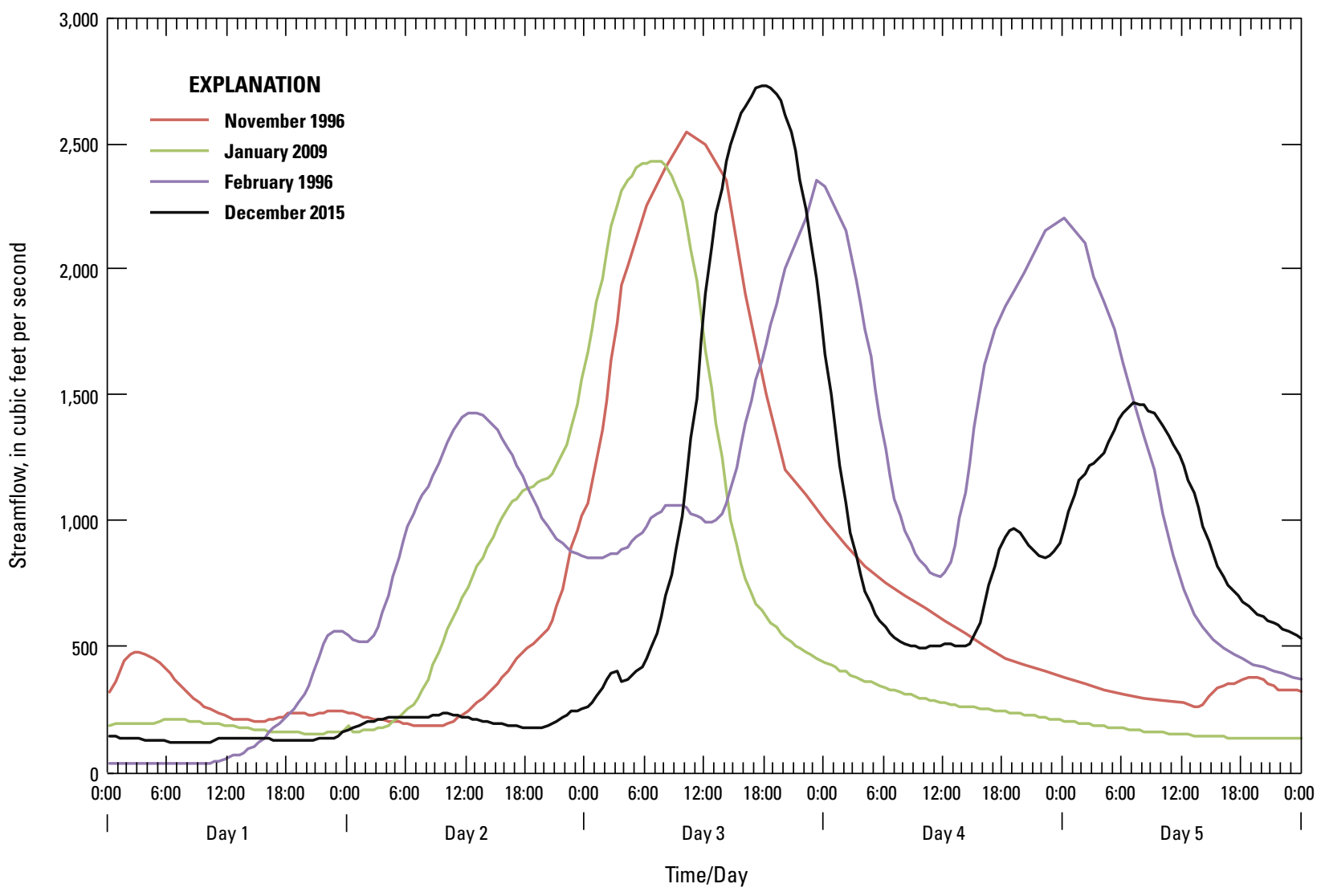

Figure 9. Comparison of large streamflow flood events at the U.S. Geological Survey streamgage on Johnson Creek at Sycamore (14211500), Oregon. 
Results for plan Unsteady_16ft_Feb1996 are similar to Plan Unsteady_16ft_smooth. The flooding around the Foster Floodplain was slightly less than Plan Unsteady_16ft_smooth (about 126 and 137 acres, respectively). These results show that the double peak had little effect on the total area inundated in the Foster Floodplain, even if it was inundated twice. These results also suggest that modest differences in hydrograph shape will not produce highly disparate inundation areas around Foster Floodplain.

To evaluate the effect of a storm event that would produce a hydrograph with an identical peak streamflow but with a much greater overall volume of streamflow, plan Unsteady_16ft_ext was developed. Plan Unsteady_16ft_ext is identical to plan Unsteady_16ft_smooth with the exceptions of the boundary condition and lateral inflow hydrographs. For plan Unsteady_16ft_ext, each hydrograph was extended to two times its original width from plan Unsteady_16ft smooth. This was done by taking the 15-minute hydrographs from plan Unsteady_16ft_smooth, and making each time increment 30 minutes (fig. 10).

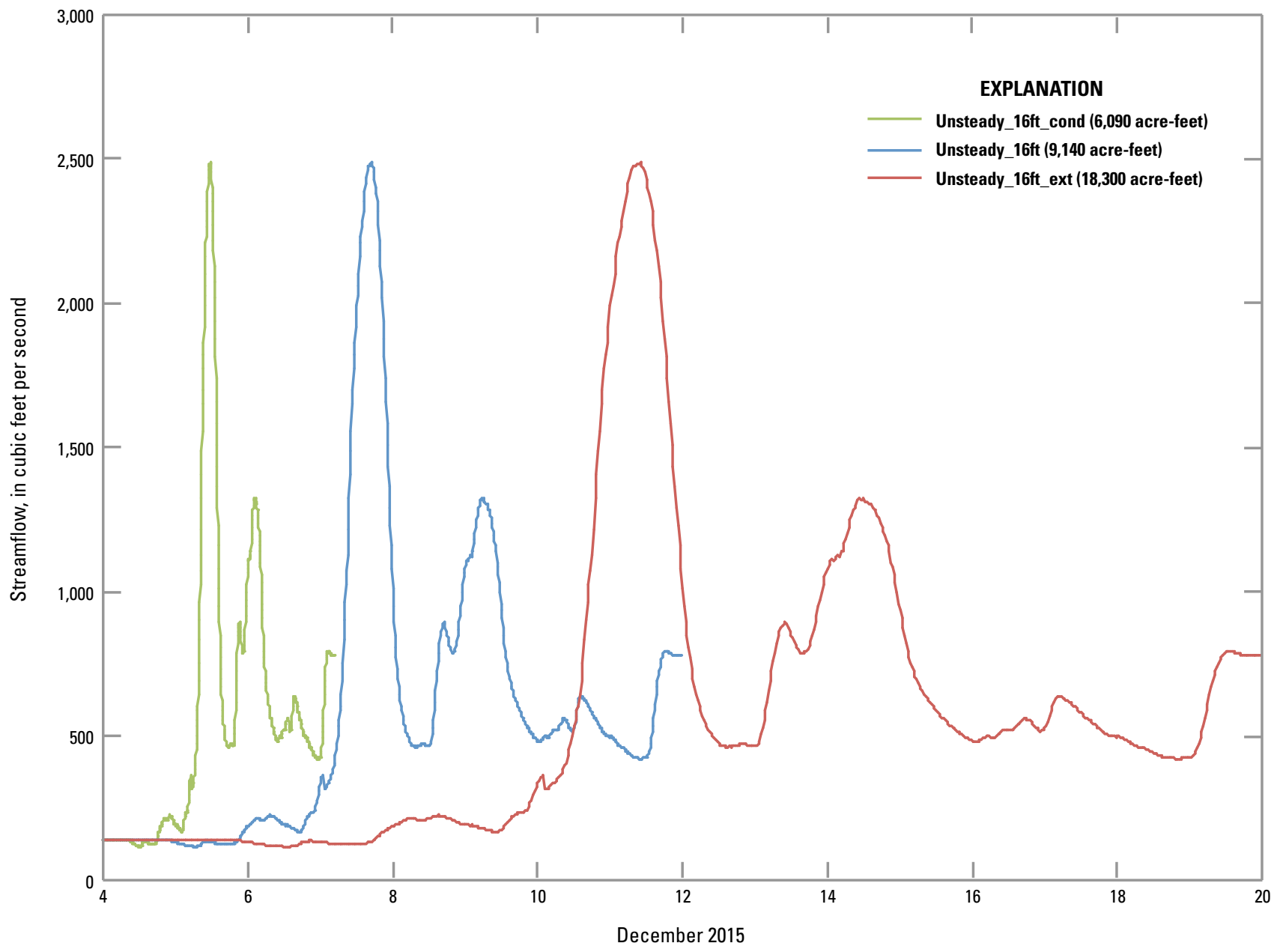

Figure 10. Upper boundary conditions for Hydrologic Engineering Center-River Analysis System Johnson Creek model plans Unsteady_16ft_cond, Unsteady_16ft, and Unsteady_16ft_ext, December 2015. 
The most significant difference between the results of plan Unsteady_16ft and plan Unsteady_16ft_ext is the area of flooding around the Foster Floodplain (fig. 11). In plan Unsteady $16 \mathrm{ft}$ smooth, water overtopped the banks and flowed through the area, but the high level of streamflow needed for overtopping the banks was not sustained for a long enough period to flood much of the area. Conversely, in plan Unsteady_16ft_ext water flowed overbank for twice as long, resulting in a larger area being flooded (about 174 acres of flood inundation in the Foster Floodplain and Johnson Creek channel for plan Unsteady $16 \mathrm{ft}$ ext, whereas plan Unsteady_16ft_smooth resulted in 138 acres). This increase in flooded areas is largely a function of the flatness of the Foster Floodplain. On average, water-surface elevations were about $0.3 \mathrm{ft}$ higher for plan Unsteady_16ft_ext than for plan Unsteady_16ft_smooth.

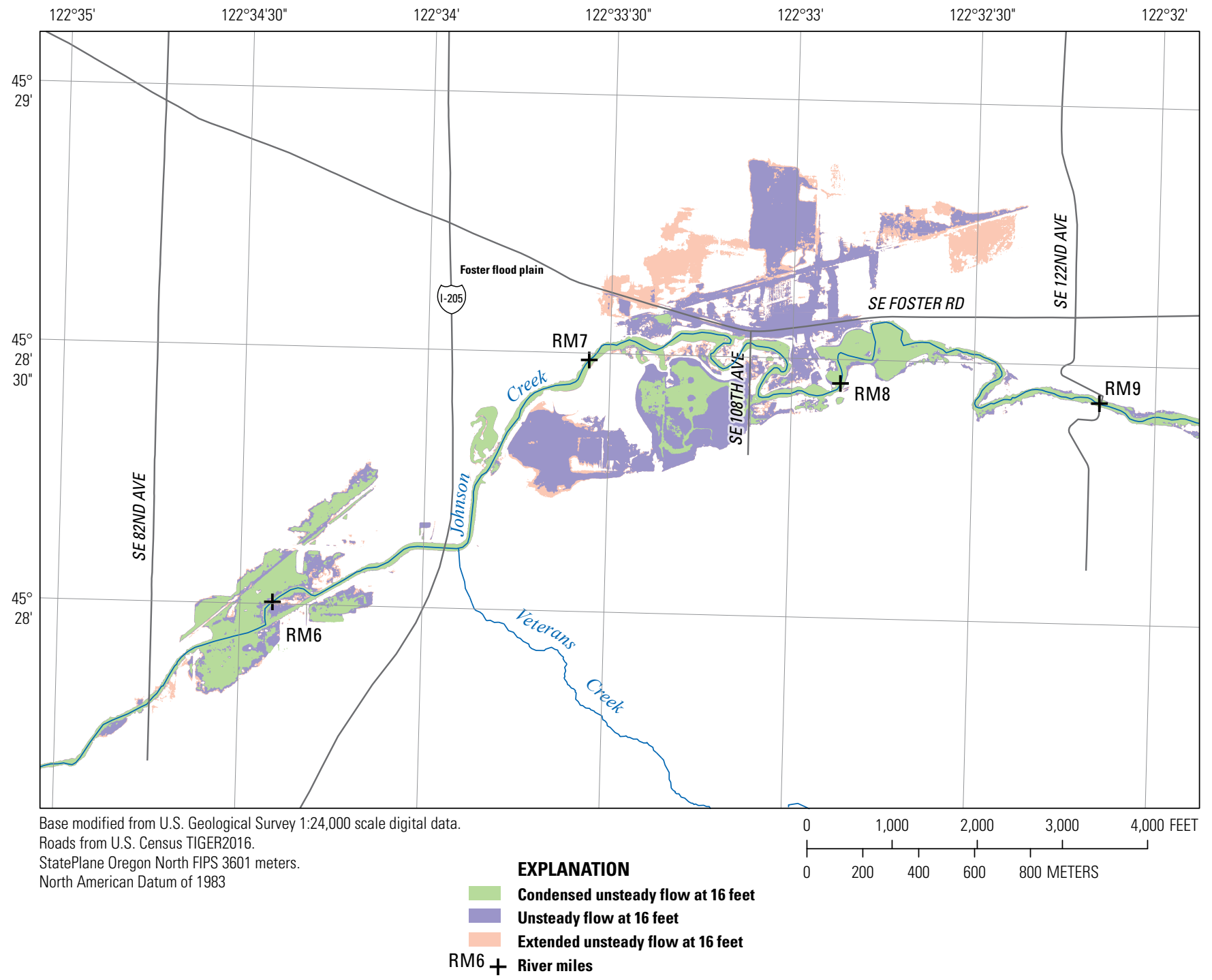

Figure 11. Comparison of condensed unsteady, unsteady, and extended unsteady flow at the U.S. Geological Survey streamgage on Johnson Creek at Sycamore (14211500) stage of 16 feet, Foster Floodplain, Portland, Oregon. 
Plan Unsteady_16ft_cond was developed to study the opposite effect of plan Unsteady_16ft_ext. Plan Unsteady_16ft_ cond represents a more localized, intensive storm event, such as a thunderstorm. Plan Unsteady_16ft_cond was developed by converting the hydrographs from Unsteady_16ft_smooth from 15- to 6-minute increments (fig. 10). Results were predictable. There was much less flooding in the Foster Floodplain (43 acres of flood inundation in the Foster Floodplain and Johnson Creek channel). Maximum water-surface elevations averaged about $0.3 \mathrm{ft}$ lower than for Unsteady_16ft_smooth.

In order to investigate the maximum possible flooding extent for a given stage at the Sycamore streamgage, "steady" plans were developed for each of the eight stages considered for this study. A steady plan allows for a specific amount of streamflow to pass through river stations in the model for an infinite amount of time. In an unsteady plan, the amount of water that passes over lateral structures and into a neighboring 2-D area is limited by the downstream progression of the hydrograph. Conversely, in a steady plan water passes over a lateral structure until the energy gradient of the water-surface elevation inside the 2-D area matches that in the channel. In effect, the steady version of the model shows the hypothetical maximum extent of flooding given a particular stage at Sycamore in the event that the high stage at Sycamore was sustained for a long period of time.

HEC-RAS does not allow for steady plans to be run when using geometry files with 2-D areas. To simulate a steady plan, plan Steady_16ft_smooth was developed by creating upper and lateral inflow boundaries that use the same hydrographs as Unsteady_16ft_smooth up to the time in which the peak streamflow is reached, and then altering the hydrograph to maintain the maximum streamflow until all 2-D areas stop filling with water (for example, fig. 12).

Results show significant differences in water-surface elevation between plans Unsteady_16ft_smooth and

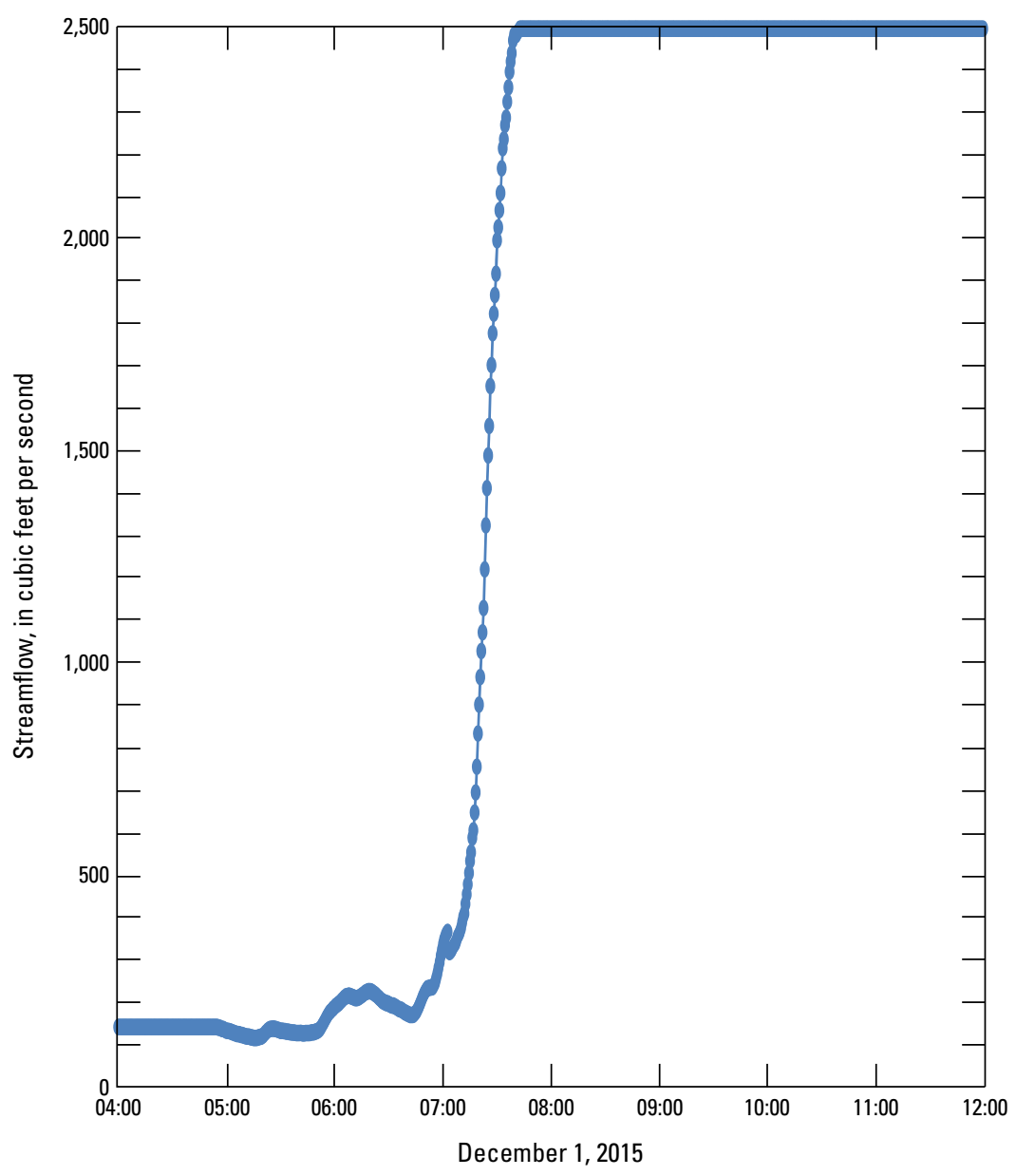

Figure 12. Upper boundary condition for streamflow input file of the steady plan at stage 16 feet, modeled on December 2015 flood event.

Steady_16ft_smooth, especially around Foster Floodplain (fig. 13) and to a lesser extent just west of SE 82nd Avenue. In effect plan Steady_16ft smooth shows the hypothetical maximum extent of flooding given a stage of $16 \mathrm{ft}$ at the Sycamore streamgage in the event that the high stage at Sycamore was sustained for a long period of time. In the case of plan Unsteady_16ft_smooth, that stage needed to be sustained for over 4 days before water stopped flowing into the Foster Floodplain.

Additional plans were developed for each of the other stages considered in this study (9-15 ft). The difference between the steady and unsteady version of each plan, and the amount of time needed at peak flow before equilibrium with the 2-D areas was reached, diminished with decreasing stage at the Sycamore streamgage. These results show that the difference between the steady and unsteady version of the plans increases with stage and that the amount of time needed for an unsteady flow to be held at peak flow levels becomes more unrealistic with increasing stage. 


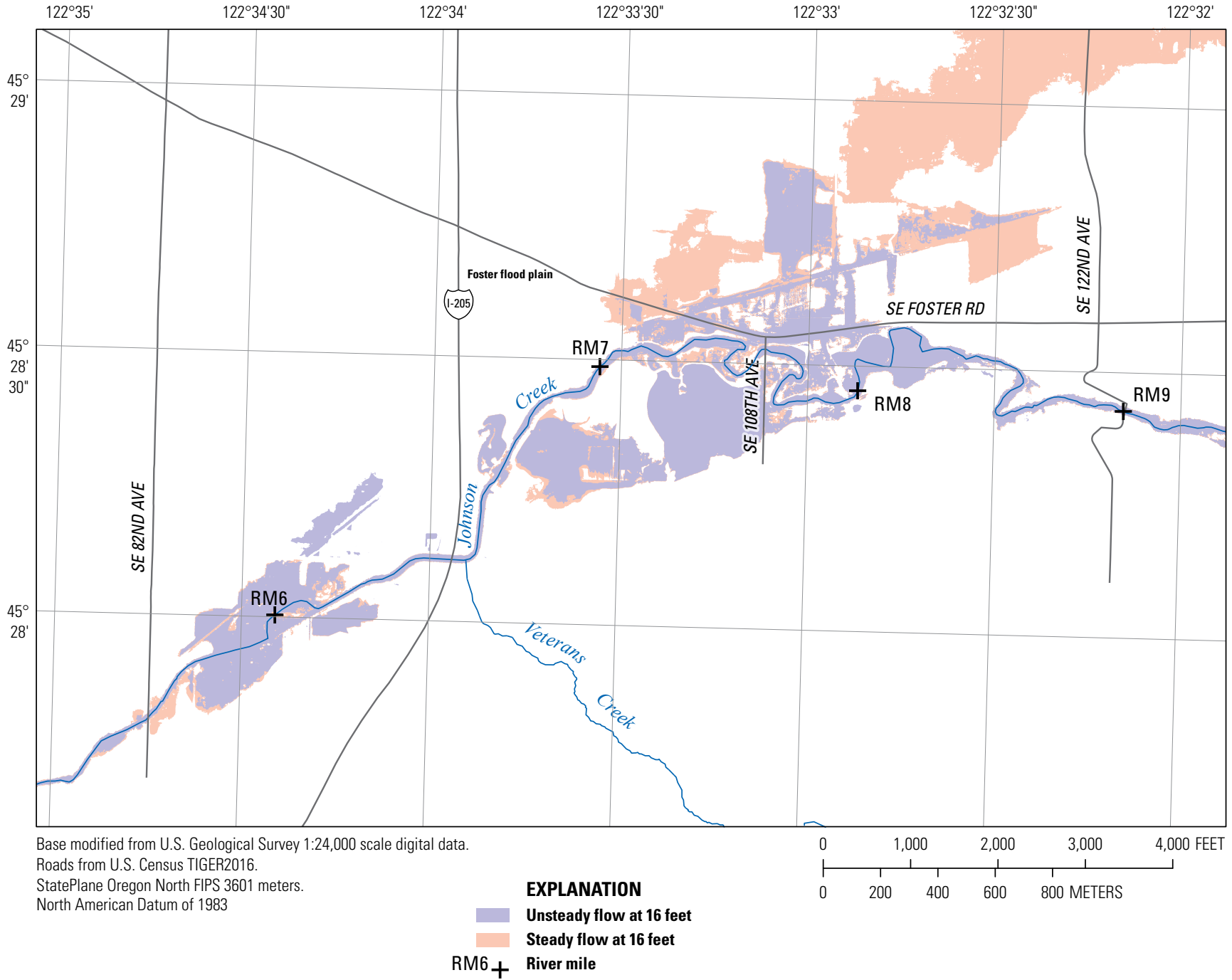

Figure 13. Comparison of unsteady and steady flow extent at the U.S. Geological Survey streamgage on Johnson Creek at Sycamore (14211500) stage of 16 feet (ft), Foster Floodplain, Portland, Oregon. 


\section{Development of Flood-Inundation Maps}

The calibrated hydraulic model was used to generate flood-inundation maps for eight stages at 1 -ft intervals between 9 and $16 \mathrm{ft}$ referenced to the Sycamore streamgage. Streamflow at each stage was derived from USGS rating curve 22.1 (table 6). The DEM data derived from the lidar have an estimated vertical Equivalent Contour Accuracy of $1 \mathrm{ft}$, which the same as $\pm 0.5 \mathrm{ft}$.

Flood-inundation maps were developed for the eight stages of interest using the water-surface profiles and underlying lidar DEM in HEC-RAS. Shapefile polygons and depth grids of the inundated areas for each plan were created and modified as needed to ensure consistent and reasonable hydraulic transitions of inundation extents between cross sections and within the 2-D flow areas.

Inundated areas detached from the main channel were evaluated for connectivity with the main channel (for example, culverts and under roadways). Areas with connections were retained in the respective flood maps. Areas without connections were removed. Bridge surfaces are displayed as inundated regardless of the water-surface elevation in relation to the bridge or low chord ${ }^{2}$ elevation.

In addition to the unsteady flow plan developed for each 1 - $\mathrm{ft}$ stage increment, the equivalent steady plan also was included in each flood-inundation map. The steady plan serves as an upper bound on uncertainty based on hydrograph shape for a given peak stage. If the true hydrograph shape were to include a larger volume of runoff for a specific peak stage, the flood-inundation extent would fall somewhere between the unsteady flow plan and the steady flow plan inundation extents shown on the map. An example of a portion of a flood-inundation map using both the unsteady and steady plans for a stage of $15 \mathrm{ft}$ is shown in figure 14 .

The area around the confluence with Crystal Springs Creek was considered an "area of uncertainty." The Crystal Springs floodplain near McLoughlin Boulevard is wide and relatively shallow compared to modeled peak water-surface elevations, especially for the largest modeled streamflows (Sycamore stages of 15 and $16 \mathrm{ft}$ ). These circumstances appear to result in a much larger areas of confluence between Johnson Creek and Crystal Springs, with the confluence beginning much farther upstream.

\section{Flood-Inundation Map Delivery}

A Flood Inundation Mapping Science Web Site (FIMWS) (U.S. Geological Survey, 2016c) was developed to make USGS flood-inundation study information available to the public. The Web site links to a mapping application that displays map libraries and other information about flooding.

\footnotetext{
${ }^{2}$ The "low chord," also called "low steel," is the point on a bridge which is the lowest part of the structure above the piers.
}

Table 6. Rating curve for the U.S. Geological Survey streamgage on Johnson Creek at Sycamore (14211500), Oregon.

[ft, feet; $\mathrm{ft}^{3} / \mathrm{s}$, cubic feet per second; NAVD 88, North American Vertical Datum of 1988]

\begin{tabular}{ccccc}
\hline $\begin{array}{c}\text { Stage } \\
\text { (ft above } \\
\text { streamgage } \\
\text { datum) }\end{array}$ & $\begin{array}{c}\text { Elevation } \\
\text { (ft above } \\
\text { NAVD 88) }\end{array}$ & $\begin{array}{c}\text { Measured } \\
\text { streamflow } \\
\left(\mathbf{f t}^{3} / \mathbf{s}\right)\end{array}$ & $\begin{array}{c}\text { Modeled } \\
\text { streamflow } \\
\text { (ft } \mathbf{3} / \mathbf{s})\end{array}$ & $\begin{array}{c}\text { Streamflow } \\
\text { difference } \\
\text { (percent) }\end{array}$ \\
\hline 9 & 238.54 & 800 & 802 & 0.3 \\
10 & 239.54 & 982 & 957 & -2.5 \\
11 & 240.54 & 1,200 & 1,191 & -0.8 \\
12 & 241.54 & 1,450 & 1,450 & 0.0 \\
13 & 242.54 & 1,750 & 1,765 & 0.9 \\
14 & 243.54 & 2,130 & 2,144 & 0.7 \\
15 & 244.54 & 2,578 & 2,606 & 1.1 \\
16 & 245.54 & 3,080 & 3,051 & -0.9 \\
\hline
\end{tabular}




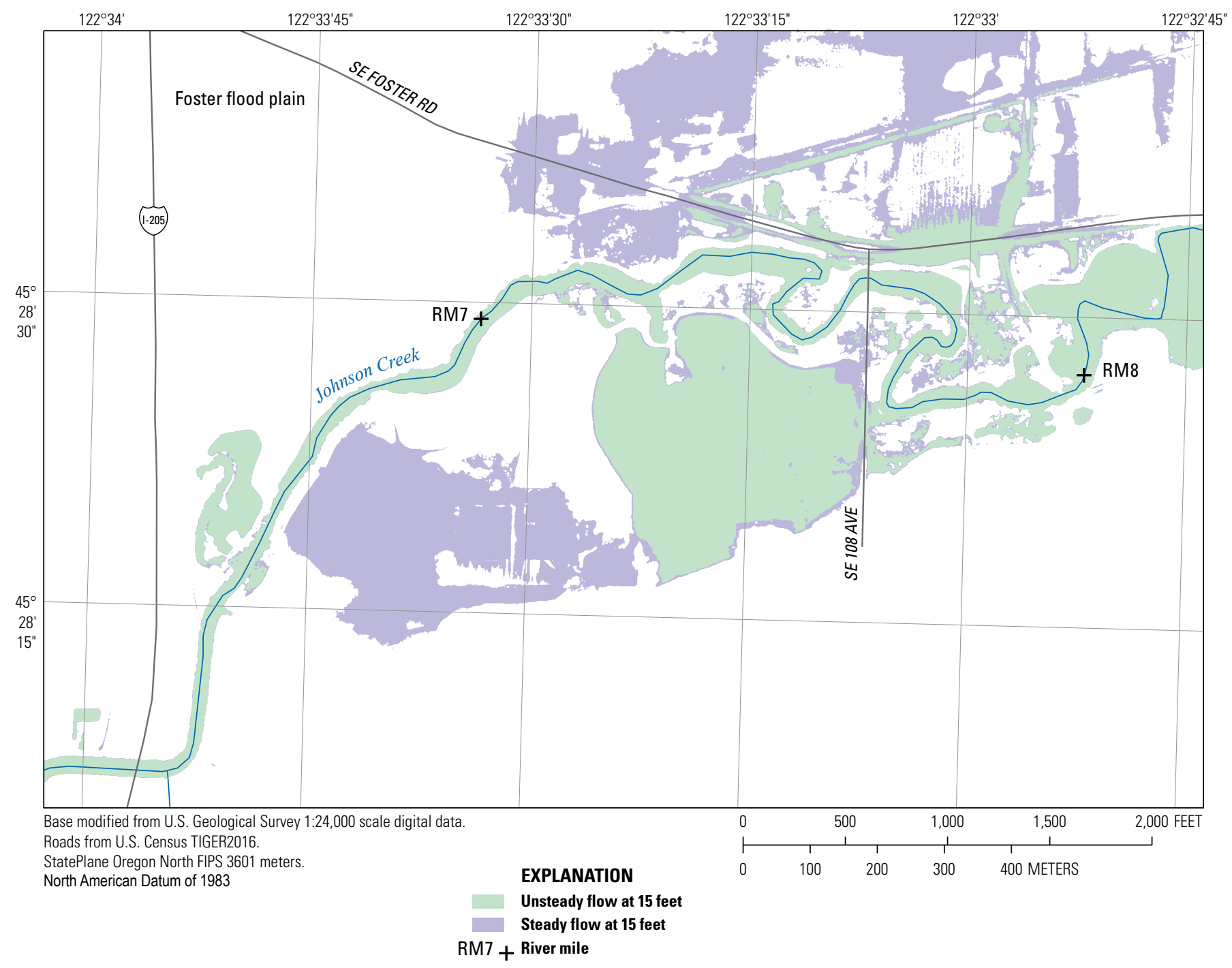

Figure 14. Comparison of steady and unsteady flow plans at U.S. Geological Survey streamgage on Johnson Creek at Sycamore (4211500) stage of 15 feet, Foster Floodplain, Portland, Oregon.

The mapping application of the FIMWS is connected to both the USGS NWIS database to display recent stage and streamflow data from the Sycamore streamgage and forecast data for the same streamgage at the National Weather Service AHPS Web site (Northwest River Forecast Center, 2016). The application user can choose a flood-inundation map based on the National Weather Service forecast, or choose a different stage. The developed flood-inundation maps provided by the USGS are displayed in sufficient detail to aid in preparations for flooding and emergency management decisions. Although bridges are always shown as submerged, roadways outside of the channel are shown as either shaded (within the flood-inundation extent) or unshaded. The application user also can click on any point within the inundation area to obtain an estimated depth of water.

All Geographic Information System files used to populate the Flood Inundation Mapping Science Web Site, and metadata associated with each file can be accessed through the USGS ScienceBase Catalog (Stonewall and Beal, 2017). 


\section{Disclaimer for Flood-Inundation Maps}

The flood-inundation maps should not be used for navigation, regulatory, permitting, or other legal purposes. The USGS provides these maps "as-is" for a quick reference, emergency planning tool but assumes no legal liability or responsibility resulting from the use of this information.

\section{Uncertainties and Limitations}

Several elements of the development of each flood-inundation map add uncertainty. All boundary condition data have some level of uncertainty, including streamflow and stage data at the USGS and BES streamgages. The stage data tend to be highly accurate at low stages, but often are biased at high stages. Streamflow values depend on the stage-discharge rating at each streamgage. At the Sycamore streamgage, the highest streamflow measurement made was $2,630 \mathrm{ft}^{3} / \mathrm{s}$ (U.S. Geological Survey, 2017), which is not too much lower than the peak streamflow measured in December $2015\left(2,740 \mathrm{ft}^{3} / \mathrm{s}\right)$. Assuming that the upper end of the stage-discharge rating is relatively stable over time, it was surmised that extending the rating past $2,630 \mathrm{ft}^{3} / \mathrm{s}$ to $2,740 \mathrm{ft}^{3} / \mathrm{s}$ should produce reasonable results. Conversely, the highest streamflow measurement made on the Milwaukie streamgage was $2,030 \mathrm{ft}^{3} / \mathrm{s}$, compared to the peak streamflow in December 2015 of 2,410 ft $\mathrm{ft}^{3} \mathrm{~s}$. While extending the Milwaukie stage-discharge rating from 2,030 to 2,410 $\mathrm{ft}^{3} / \mathrm{s}$ is still reasonable, there is a larger gap between the highest measured streamflow and the top of the rating, which produces more chance for error.

In addition to any inherent uncertainty in the rating itself, large storm events often result in changes to the rating. The lidar data used and the surveyed geospatial data have inherent uncertainties as well. The lidar data have a vertical resolution of $0.3 \mathrm{ft}$, and the geospatial data are presumed to have a degree of uncertainty similar to the published benchmarks that were surveyed (root-mean squared error of $0.11 \mathrm{ft}$, table 3 ).

Much of the bathymetry data used in the model is from the FIS model. It is not known when those bathymetry data were collected, or how representative those data are of current conditions. Other model assumptions include no major changes to roughness, and no backwater from localized debris or beaver dams. In addition, the high water marks used in model calibration often were less than ideal. CSG marks tend to be collected near bridges, where large changes in the energy gradient make precise modeling of water-surface elevations difficult. Other high water marks, such as seed lines and debris, were usually not obvious, so some degree of uncertainty is assumed $( \pm 1 \mathrm{ft})$.

End users also should be aware of inherent uncertainties in the NWS river forecasts displayed on the Flood Inundation Mapper Web site (http://wimcloud.usgs.gov/apps/FIM/ FloodInundationMapper.html). NWS river forecasts include uncertainties in the estimates of runoff generated for specific storms, the simulation of the movement of floodwater, and the prediction of flow and stage values at streamgages of interest. For more information on AHPS forecasts, see National Weather Service (2016).

Based on the assumed accuracy of the lidar data, high water marks, and stage-discharge relationship, modeled results for all stages are considered fair. Results are considered fair at higher stages due to potential uncertainties regarding the high end of the stage-discharge rating curve at the Sycamore streamgage, which is based on extrapolation at stages near $16 \mathrm{ft}$. At lower stages, the stage-discharge relationship is not based on extrapolation and likely to be more accurate. However, results from the lower stages are only considered fair because the model was calibrated at a high stage $(15.33 \mathrm{ft})$. Assumptions such as the timing of lateral inflows and the upstream boundary hydrograph shape from this high stage may be less accurate at lower stages.

\section{Suggestions for Future Research}

Future updates to the model may be warranted if more of the watershed area is restored to more natural conditions or developed, and if more flood storage is added. In addition, future investigations (indirect streamflow measurements) may result in a new estimate of peak streamflow for the December 2015 flood. If this new estimate were to be significantly different from the current estimate, a new calibration of the model may be warranted.

\section{Summary}

A U.S. Army Corps of Engineers Hydrologic Engineering Center-River Analysis System model of Johnson Creek was developed and calibrated using data from the December 2015 flood event. The model was then checked against the January 2009 flood event. Errors within the calibration and the plan used to check the model were determined to be within acceptable limits. Four sensitivity analyses were used to evaluate the effects of hydrograph shape and volume on the flood extent given a specific stage value at the Sycamore streamgage.

Eight digital flood-inundation maps were developed by the U.S. Geological Survey in cooperation with the City of Portland Bureau of Environmental Services. The maps cover about 12.9 river miles of Johnson Creek in northwest Oregon, from around SE 174th Avenue to the confluence with the Willamette River. The eight maps were developed using the (HEC-RAS) program to delineate estimated flood-inundation areas, calculate depths, and compute water-surface profiles for specific stages associated with the Sycamore streamgage. The HEC-RAS hydraulic model was calibrated using data associated with the December 2015 flood, including recorded 
data from two streamgages, 10 high water marks, and four recorded water-surface elevations from crest stage gages. The maps show flood-inundation areas and depths in the study area for stream stages between 9.0 and 16.0 feet at 1-foot intervals.

The flood maps are available through the mapping application on the U.S. Geological Survey Flood Inundation Mapper Web site (http://wimcloud.usgs.gov/apps/FIM/ FloodInundationMapper.html). The Flood Inundation Mapper can be used by the general public to read forecasted flood stage data from the National Weather Service Advanced Hydrologic Prediction Service for the Sycamore streamgage, to select the appropriate flood-inundation map and identify shaded areas expected to be inundated, and to select areas of flood inundation to see estimates of water-surface depth. The Flood Inundation Mapper Web site will provide emergency management personnel with a tool to help manage both emergency flood operations during storm events and post flood recovery efforts. In addition, the Web site can be used by the general public for safety precautions and flood preparedness.

\section{Acknowledgments}

The authors gratefully acknowledge the support of the City of Portland Bureau of Environmental Services, in particular, Maggie Skendarian and Ali Young; Gary Wolff from Otak, Inc., and USGS personnel, Glen Hess and volunteer Jenny Borth.

\section{References Cited}

City of Portland Bureau of Environmental Services, 2017, Johnson Creek Watershed: The City of Portland, Bureau of Environmental Services, Web site, accessed February 15, 2017, at https://www.portlandoregon.gov/bes/32201.

Dewberry, 2016, USGS National Enhanced Elevation Assessment: Arlington, Virginia, Final Report, 84 p., accessed October 17, 2016, at http://www.dewberry. $\mathrm{com} /$ docs/default-source/documents/neea_final-report_ revised-3-29-12.pdf?sfvrsn=0.

East PDX News, 2012, Flooding disaster averted along Johnson Creek: East PDX News, Web site, accessed April 21, 2016, at http://eastpdxnews.com/general-newsfeatures/flooding-disaster-averted-along-johnson-creek-2/.

Federal Emergency Management Agency, 2010, Flood Insurance Study - City of Portland, Oregon, Multnomah, Clackamas and Washington Counties: Federal Emergency Management Agency, v. 1, November 26, 2010.
Johnson Creek Watershed Council, 2012, Johnson CreekState of the watershed: Johnson Creek Watershed Council report May 2012, 6 p., accessed April 12, 2016, http://jcwc. org/wp-content/uploads/2012/05/2012StateoftheWatershed. pdf.

Johnson, Steve, 1992, History of Johnson Creek Canyon: Johnson Creek Watershed Council, Web site document, 6 p., accessed April 12, 2016, at http://jcwc.org/wp-content/ uploads/2012/03/History-of-Johnson-Creek-Canyon1.pdf.

Kenney, T.A., 2010, Levels at gaging stations: U.S. Geological Survey Techniques and Methods, book 3, chap. A19, 60 p.

Northwest River Forecast Center, 2016, River information and forecasts—Johnson Creek at Sycamore: National Oceanic and Atmospheric Administration, Web site, accessed October 7, 2016, at http://www.nwrfc.noaa.gov/river/ station/flowplot/flowplot.cgi?lid=SYCO3.

National Oceanographic and Atmospheric Administration, 2016, Orthometric height conversion: Web site, accessed October 21, 2016, http://www.ngs.noaa.gov/cgi-bin/ VERTCON/vert_con.prl.

National Weather Service, 2016, A brief overview of the NWS precipitation and river forecasting and the river forecast on the AHPS hydrograph: National Weather Service, Web site document, 1 p., accessed October 21, 2016, at http://water. weather.gov/ahps/pcpn_and_river_forecasting.pdf.

Oregonlive, 2015a, Historically high Johnson Creek floodwaters put squeeze on small, Portland office-supply company: Oregonlive, Web site of The Oregonian, accessed April 21, 2016, at http://www.oregonlive.com/portland/ index.ssf/2015/12/historically_high_flood_water.html.

Oregonlive, 2015b, SE Portland apartment complex residents evacuate as flooding precaution: Oregonlive, Web site of The Oregonian, accessed April 21, 2016, at http://www. oregonlive.com/portland/index.ssf/2015/12/se_portland_ low-income_housing.html\#incart_big-photo.

Portland Development Commission, 2013, Foster Road flood mitigation strategy —Executive summary: Lents Action Plan, Appendix 12, accessed October 21, 2016, at http:// www.pdc.us/Libraries/Lents_Action_Plan/Lents_Action Plan_-_Appendix_12_pdf.sflb.ashx.

Rydlund, P.H., Jr., and Densmore, B.K., 2012, Methods of practice and guidelines for using survey-grade global navigation satellite systems (GNSS) to establish vertical datum in the United States Geological Survey: U.S. Geological Survey Techniques and Methods, book 11, chap. D1, 102 p. with appendixes. 
Stonewall, Adam, 2014, Water levels at the 0.01 annual exceedance probability at the Glenwood Street and Bybee Boulevard crossings of Crystal Springs Creek, Portland, Oregon: U.S. Geological Survey Webpage, http://dx.doi. org/10.5066/F7ZK5DP0.

Stonewall, A.J., and Beal, B.A., 2017, Flood Inundation Mapping Data for Johnson Creek near Sycamore, Oregon: U.S. Geological Survey data release, https://doi. org/10.5066/F75X273G.

Stonewall, Adam, and Hess, Glen, 2016, Evaluation of flood inundation in Crystal Springs Creek, Portland, Oregon: U.S. Geological Survey Open-File Report 2016-1079, 33 p., http://dx.doi.org/10.3133/ofr20161079.

U.S. Army Corps of Engineers, 2016, HEC-RAS River Analysis System, hydraulic reference manual, (version 5.0): Davis, California, U.S. Army Corp of Engneers, accessed March 7, 2016, at http://www.hec.usace.army.mil/ software/hec-ras/documentation/HEC-RAS\%205.0\%20 Reference\%20Manual.pdf.

U.S. Geological Survey, 2015, StreamStats-Oregon: U.S. Geological Survey database, accessed May 29, 2015, at http://water.usgs.gov/osw/streamstats/oregon.html.

U.S. Geological Survey, 2016a, Johnson Creek at Sycamore, OR station 14211500-Top 10 floods from water year 1941-2016: Oregon Water Science Center Web site document, 1 p., accessed October 21, 2016, at http:// or.water.usgs.gov/jcrk/images/jcs_top10.pdf.
U.S. Geological Survey, 2016b, National Water Information System-Water data for the nation: U.S. Geological Survey database Web interface, accessed May 3, 2016, at http:// waterdata.usgs.gov/nwis/.

U.S. Geological Survey, 2016c, USGS flood inundation mapping science-Flood inundation mapping (FIM) program: U.S. Geological Survey Web site, accessed April 19, 2016, at http://water.usgs.gov/osw/flood_ inundation.

U.S. Geological Survey, 2016d, USGS 14211500 Johnson Creek at Sycamore, OR: U.S. Geological Survey National Water Information System database Web interface, accessed October 21, 2016, at http://waterdata.usgs.gov/or/nwis/ inventory/?site_no=14211500\&agency_cd=USGS.

U.S. Geological Survey, 2017, Streamflow measurements for Oregon: U.S. Geological Survey National Water Information System database Web interface, accessed February 15, 2017, at https://waterdata.usgs.gov/or/nwis/ measurements/?site_no $=14211500 \&$ agency_cd=USGS.

WSI, 2015, OLC Metro 2014-Final delivery: WSI, Quantum Spatial Company, data report, accessed October 21, 2016, at http://www.oregongeology.org/pubs/ldq/reports/OLC_ Metro_2014_Data_Report-and_Hydroflattening_Project. pdf. 
Publishing support provided by the U.S. Geological Survey Science Publishing Network, Tacoma Publishing Service Center

For more information concerning the research in this report, contact the Director, Oregon Water Science Center

U.S. Geological Survey

2130 SW 5th Avenue

Portland, Oregon 97201

http://or.water.usgs.gov 
c)

옹 